\title{
Synthesis, Biological Evaluation and Molecular Docking of Combretastatin and Colchicine Derivatives and their hCE1- Activated Prodrugs as Antiviral Agents
}

\author{
Michael Richter, ${ }^{[a]}$ Veaceslav Boldescu, ${ }^{[a, d]}$ Dominik Graf, ${ }^{[a]}$ Felix Streicher, ${ }^{[a]}$ Anatoli Dimoglo, ${ }^{[b]}$ Ralf \\ Bartenschlager ${ }^{[\mathrm{c}]}$ and Christian D. Klein ${ }^{[\mathrm{a}] *}$
}

[a] M. Richter, ORCID 0000-0002-8227-0543

Dr. V. Boldescu, ORCID 0000-0003-0709-2086

Dr. D. Graf, ORCID 0000-0002-6124-8451

F. Streicher, ORCID 0000-0002-8375-2958

Prof. Dr. C.D. Klein, ORCID 0000-0003-3522-9182

Institute of Pharmacy and Molecular Biotechnology

Heidelberg University

INF 364, D-69120 Heidelberg, Germany

*E-mail: c.klein@uni-heidelberg.de

[b] Prof. A. Dimoglo, ORCID 0000-0001-8638-3679

Faculty of Engineering

Duzce University

Duzce, Turkey

[c] Prof. Dr. R. Bartenschlager, ORCID 0000-0001-5601-9307

Department of Infectious Diseases, Molecular Virology,

Heidelberg University

INF 344, D-69120 Heidelberg, Germany

[d] Dr. V. Boldescu

Laboratory of Organic Synthesis and Biopharmaceuticals

Institute of Chemistry

Academiei str. 3, MD2028 Chisinau, Moldova

Supporting information for this article is given via a link at the end of the document

\begin{abstract}
Recent studies indicate that tubulin can be a host factor for vector borne flaviviruses like dengue (DENV) and Zika (ZIKV) and inhibitors of tubulin polymerization like colchicine have been demonstrated to reduce virus replication. However, toxicity limits the application of these compounds. Herein, we report prodrugs based on combretastatin and colchicine derivatives that contain anan ester cleavage site for human carboxylesterase, a highly abundant enzyme in monocytes and hepatocytes targeted by DENV. Compared to their parent compounds, the cytotoxicity of these prodrugs was reduced by several orders of magnitude. All synthesized prodrugs containing the leucine ester were hydrolyzed by the esterase in vitro. In contrast to previous reports, the phenylglycine esters were not cleaved by human carboxylesterase. Antiviral activity of combretastatin, colchicine and selected prodrugs against DENV and ZIKV in cell culture was observed at low micromolar and submicromolar concentrations. In addition, docking studies were performed to understand the binding mode of the studied compounds to tubulin.
\end{abstract}

\section{Introduction}

The development of new antiviral agents against flaviviruses remains a great necessity due to the lack of efficient vaccines or other options for prevention or treatment of infectious diseases caused by some of the most spread species of the Flavivirus family - dengue, West Nile, and Zika viruses. Dengue is considered the most common viral infection transmitted by an arthropod with an estimated number of infections ranging from 50-100 million per year, of which $10-20$ thousand are lethal. ${ }^{[1,2]}$
The increasing number of co-circulating flaviviruses, as well as the emergence of new human infections caused by arboviruses, ${ }^{[3]}$ make it desirable to develop agents with broadspectrum activity. ${ }^{[4]}$ It appears promising to target host factors, which carry a lower risk of resistance development and have higher potential for broad-spectrum activity. ${ }^{[5]}$ A major disadvantage and risk of targeting host factors, however, can arise from interference with physiological host processes and subsequent toxicity. One possible rationale to overcome this disadvantage is the design of prodrugs which are specifically activated within the virus-infected cells, or within those cells that are preferably targeted by the virus.

The present work is based on the hypothesis that agents influencing microtubule dynamics could be used in subcytotoxic concentrations as systemic antiviral agents. A related, successful example from clinical practice is the use of podophyllotoxin as topical medication (Podofilox) to treat warts that are often induced by infections with the human papilloma virus. ${ }^{[6]}$

Tubulin ligands have the potential to inhibit the replication of those viruses that depend on the microtubule network, such as ZIKV and DENV. ${ }^{[7]}$ Thus, these inhibitors might be suitable as possible broad-spectrum anti-flaviviral or even broad-spectrum antiviral agents.

We hypothesized that prodrugs of tubulin polymerization inhibitors (TPIs) which are specifically activated in cells of the monocyte-macrophage lineage and hepatocytes, which are preferential targets of flaviviruses, would spare non-affected cells and tissues from non-specific, toxic tubulin inhibition effects.

Microtubules and the cytoskeleton have been intensively studied and found to be involved in several steps of the flaviviral 
replication cycle, such as viral entry, intracellular transport, virion assembly and egress. ${ }^{[8,9]}$ Although the involvement of microtubules in cell entry of DENV has been reported to be crucial, ${ }^{[10,11]}$ other reports suggest a microtubule-independent cell entry of different DENV serotypes. ${ }^{[12]}$ Also in these cases, microtubules might be a non-essential, but nevertheless supportive factor for the infection of cells. ${ }^{[12]}$

The intracellular transport of viral particles in the host cell, including their trafficking to assembly sites in later stages of the infection, is performed by microtubules and their associated proteins. ${ }^{[13]}$ Tubulin was found to be 3.3-fold overexpressed in patients with dengue haemorrhagic fever. ${ }^{[14]}$ Acosta et al. have demonstrated that inhibitors of microtubule polymerization cause a significant reduction in virus production. ${ }^{[15]}$ These authors also suggested that the structural integrity of the microtubule network is required for efficient entry of DENV into cells.

Tubulin structures in DENV-infected cells were described to assist in the scaffold assembly of the virus through interactions with the viral envelope $(E)$ protein. ${ }^{[16]}$ The microtubule-stabilizing agent paclitaxel has been shown to reduce the viral titre of ZIKV in Huh-7 cells, which suggests an important role of microtubule dynamics in ZIKV replication. ${ }^{[17]}$ Chen et al. have suggested that a microtubule destabilizing agent, colchicine, induced an enhanced release of DENV from infected cells, ${ }^{[12]}$ however the influence on viral replication has not been explored in that study.

The main target cells for DENV are immune cells of the macrophage-monocytic lineage (Langerhans cells, splenic macrophages, tissue macrophages, Kupffer cells) as well as hepatocytes and endothelial cells. ${ }^{[18,19]}$ A potential activator enzyme for prodrugs that is highly expressed in these cells is the human carboxylesterase-1 (hCE1). ${ }^{[20,21]}$ Depending on the design of the prodrug, intracellular hydrolysis of a drug-ester conjugate by hCE1 results in the formation of an active compound with increased polarity, lower membrane permeability and a tendency to accumulate within the targeted cells. ${ }^{[22]}$ The concept has already been applied to some antiarthritic ${ }^{[22]}$ compounds and imaging agents. ${ }^{[23]}$ hCE1 was described to cleave preferably at the two cleavage motifs shown in Figure 1, the cyclopentanol esters of phenylglycine (Phg) and leucine. We therefore chose to use these motifs in the design of hCE1 activated tubulin-ligand prodrugs.

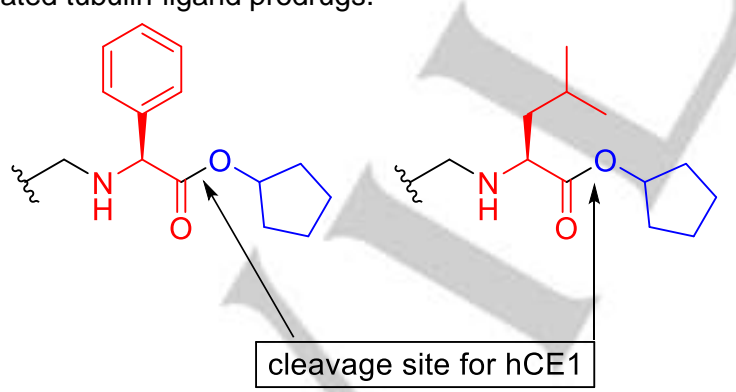

Figure 1. hCE1 selective motifs according to Needham et al. ${ }^{[22]}$ : Cyclopentyl esters of phenylglycine and leucine are hydrolyzed by human carboxylesterase 1 to form cyclopentanol and the corresponding carboxylate.

Numerous microtubule-stabilizing and -destabilizing compounds are derived from natural products and have been modified by partial or complete synthesis. The microtubuledestabilizing alkaloid colchicine binds into a pocket between the $\alpha$ - and $\beta$-tubulin subunits ${ }^{[24]}$ and thereby inhibits tubulin polymerization. The "colchicine binding site" is also targeted by the combretastatins, another group of natural products ${ }^{[25]}$ whose most potent member (combretastatin A4) has similar affinity to tubulin as colchicine. ${ }^{[26]}$ The combretastatins and their synthetic analogues are accessible via Wittig reaction of two substituted aromatic rings, which allows a straightforward synthesis of many derivatives. Moreover, functional groups like amines and carboxylic acids can be attached, rendering combretastatin an attractive object for derivatization. As shown in Figure 2, the hydroxyl group in position 3 of the B-ring is not essential for activity, which makes this position attractive for the attachment of prodrug moieties. A phosphoric acid ester attached at this position yields a prodrug with increased aqueous solubility (fosbretabulin) which showed potent anti-tumour activity in clinical trials phase II. ${ }^{[27]}$

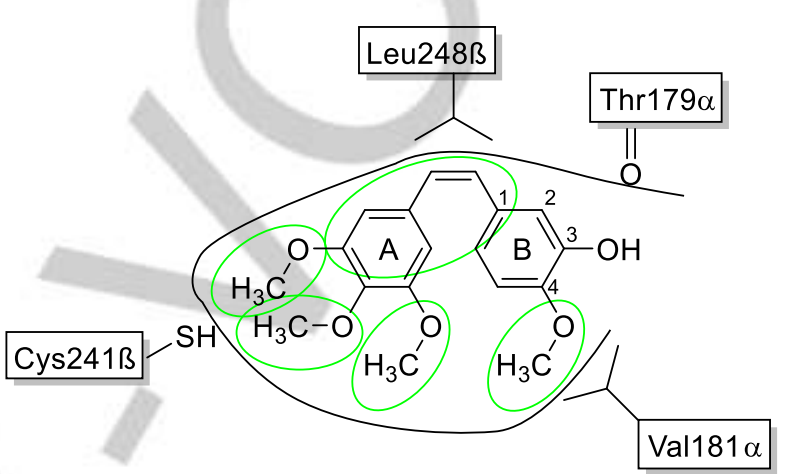

Figure 2. Structure-activity relationships of the combretastatins. Shown is combretastatin A-4 in the tubulin binding pocket (PDB code: $5 \mathrm{LYJ}$ ) with the established labelling of the carbon atoms. Essential structural elements are marked in green: in particular, these are the four methoxy groups and the cisconfigured double bond with the surrounding hydrophobic area. ${ }^{[25]}$ For reviews of the SAR, see ${ }^{[28-30]}$.

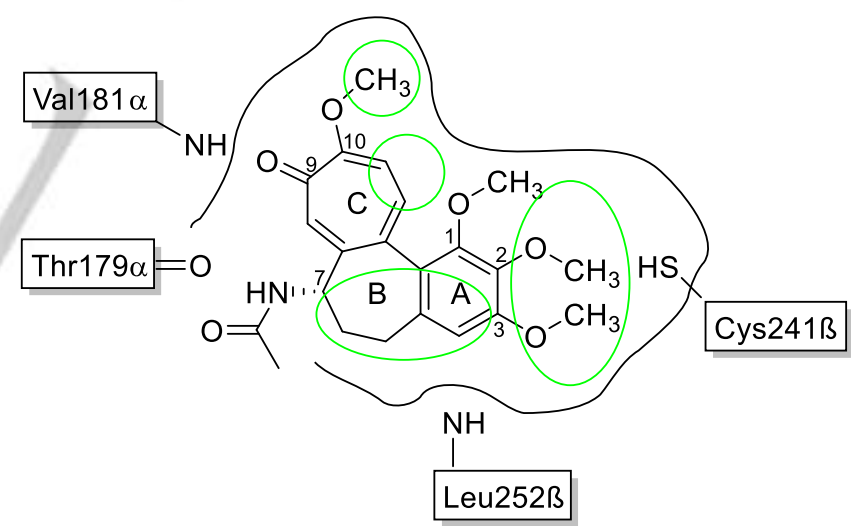

Figure 3. Outline of the most important characteristics of a molecule of colchicine situated in a colchicine-binding site of tubulin (PDB code: 4O2B) as identified by SAR, hydropathic analysis and 3D-QSAR. The area marked with green colour indicates specific steric barriers of the binding site. ${ }^{[31]}$

The main problem regarding the use of colchicine and other tubulin polymerization destabilizers as antiviral drugs is their high systemic toxicity. Colchicine causes a complete inhibition of tubulin assembly at substoichiometric concentrations ${ }^{[32]}$ and has strong anti-angiogenic effects, a typical feature of microtubule disrupting agents, which is now seen to provide a promising approach for the treatment of cancer. ${ }^{[33,34]}$

Previous attempts to decrease the systemic toxicity of colchicine often resulted in a significant drop or total loss of biological activity. ${ }^{[35]}$ A structural analysis of the colchicine binding site of tubulin reveals that mainly the A-ring of colchicine 
and its substituents interact with the target whereas the B- and especially C-ring offer potential for derivatization for the purpose of toxicity reduction (Figure 3).

Although sterically limited, due to the structure of the colchicine-binding site, the most prominent position for introducing structural alterations is the 10-methoxy group situated in ring $\mathrm{C}$. Replacements at this position and the amino group at position 7 resulted in compounds with similar or lower cytotoxicity as that of colchicine and higher selectivity of action towards specific cells, e.g. cancer cells. ${ }^{[34,36-38]}$ Particularly promising is the replacement of the 10-methoxy group by aminecontaining scaffolds such as amino acids, or ammonia. ${ }^{[39,40]}$ Small substituents in that position are well tolerated, whereas long or bulky moieties have a detrimental effect on activity. ${ }^{[34]}$

Considering the SAR outlined above, the tolerance of tubulin towards modified ligands, and the synthetic accessibilities, we chose position B-3 in combretastatin (see Figure 2) and position 10 in colchicine (see Figure 3 ) as connecting points for attachment of prodrug moieties. We anticipated that larger moieties, i.e., those present in the prodrugs in these positions, would cause a loss in tubulin affinity, rendering the prodrugs inactive. In contrast, upon cleavage of the prodrug, we expected the remaining attachment structures to be tolerated by tubulin.

Molecular modelling of biochemical processes makes it possible to understand at a deeper level the mechanism of interaction in the ligand-protein complex. ${ }^{[41]}$ This knowledge can be used to search for and synthesize new active compounds with specific properties. Based on available experimental data about the inhibition of tubulin polymerization, in recent years there have been many studies related to the molecular modelling and docking of various classes of chemical compounds in the colchicine binding site of tubulin. ${ }^{42-50]}$

In one of the first studies ${ }^{[42,43]}$ devoted to the docking of various ligands into the colchicine binding site of tubulin, it has been shown that the binding of colchicine derivatives to the active site of $\alpha$-tubulin is due to the formation of hydrogen bonds of colchicines with amino acids such as His28, Ser232, Cys356 and Arg320. For $\beta$-tubulin, binding occurs with Thr33 and Tyr36.

In several subsequent studies, ${ }^{[44-46]}$ cytotoxic properties of the compounds turned out to be due to their ability to inhibit the polymerization of tubulin. Based on the results of docking, the authors draw conclusions about the relationship between compound cytotoxicity and the way the compounds dock onto the receptor. This correlates well with the antitumor activity of these compounds. Other studies ${ }^{[47,49-52]}$ have been devoted to the modelling of pharmacophores, docking and virtual screening of various tubulin inhibitors. The authors use the obtained pharmacophore model of inhibition of tubulin to draw conclusions on the antitumor activity relative to new potentially active compounds.

\section{Results and Discussion}

\section{Synthesis of Combretastatin- and Colchicine-Based Derivatives}

The hCE1-sensitive motifs used for derivatization were obtained according to the method described by Charlton et al. ${ }^{[23}$ with modification for the phenylglycine-based motif as described in the Experimental Section. The obtained motifs were connected to the active compounds via an amide bond. Therefore, in the structure of combretastatin, the hydroxyl group was replaced by a carboxylic acid group. To modulate activity, toxicity and lipophilicity of the esters, alkyl spacers based on 4aminobutyric acid and 8-aminooctanoic acid were inserted between combretastatin and the hCE1-sensitive motif (Scheme 1). For the synthesis of colchicine $\mathrm{C}_{10}$-derivatives, we chose the synthetic approaches provided in Scheme 2, using colchicine as starting material. Modifications included substitution of the methoxy group with amino functionalities (ammonia or amino acid derivatives) in position 10. The formed 10 -aminocolchicine or its derivatives were subjected to further transformations via coupling reactions with the hCE1-sensitive motif to obtain the final compounds (Scheme 2). The spacers connecting the 10-aminocolchicine molecule to the hCE1sensitive motif were chosen to convey higher hydrophobicity to the esters and thereby facilitate its penetration through the cellular membrane and interaction with the hydrophobic pocket of the colchicine-binding site.

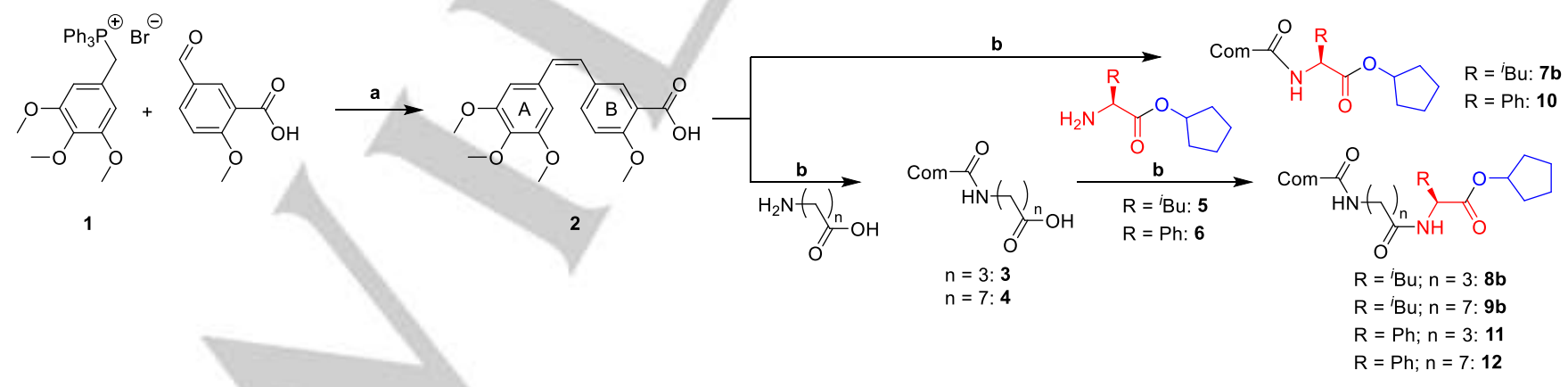

Scheme 1. Synthesis of B-3-combretastatin derivatives: Combretastatin carboxylic acid (2) was formed in a Wittig reaction between the phosphonium salt 1 and the aromatic aldehyde. The coupling of the amino acid cyclopentyl ester and - if applicable - the alkyl spacer was performed in solution with the coupling reagent 1-[Bis(dimethylamino)methylene]-1H-1,2,3-triazolo[4,5-b]pyridinium 3-oxid hexafluorophosphate (HATU). Conditions: $\mathbf{a}=\mathrm{BuLi}, \mathrm{THF}, 0^{\circ} \mathrm{C} \rightarrow \mathrm{rt}, 12 \mathrm{~h} . \mathbf{b}=$ HATU, DMF, $0^{\circ} \mathrm{C} \rightarrow \mathrm{rt}, 24 \mathrm{~h}$. The structural element of the amino acid (phenylglycine or leucine) is marked in red, cyclopentanol in blue. 


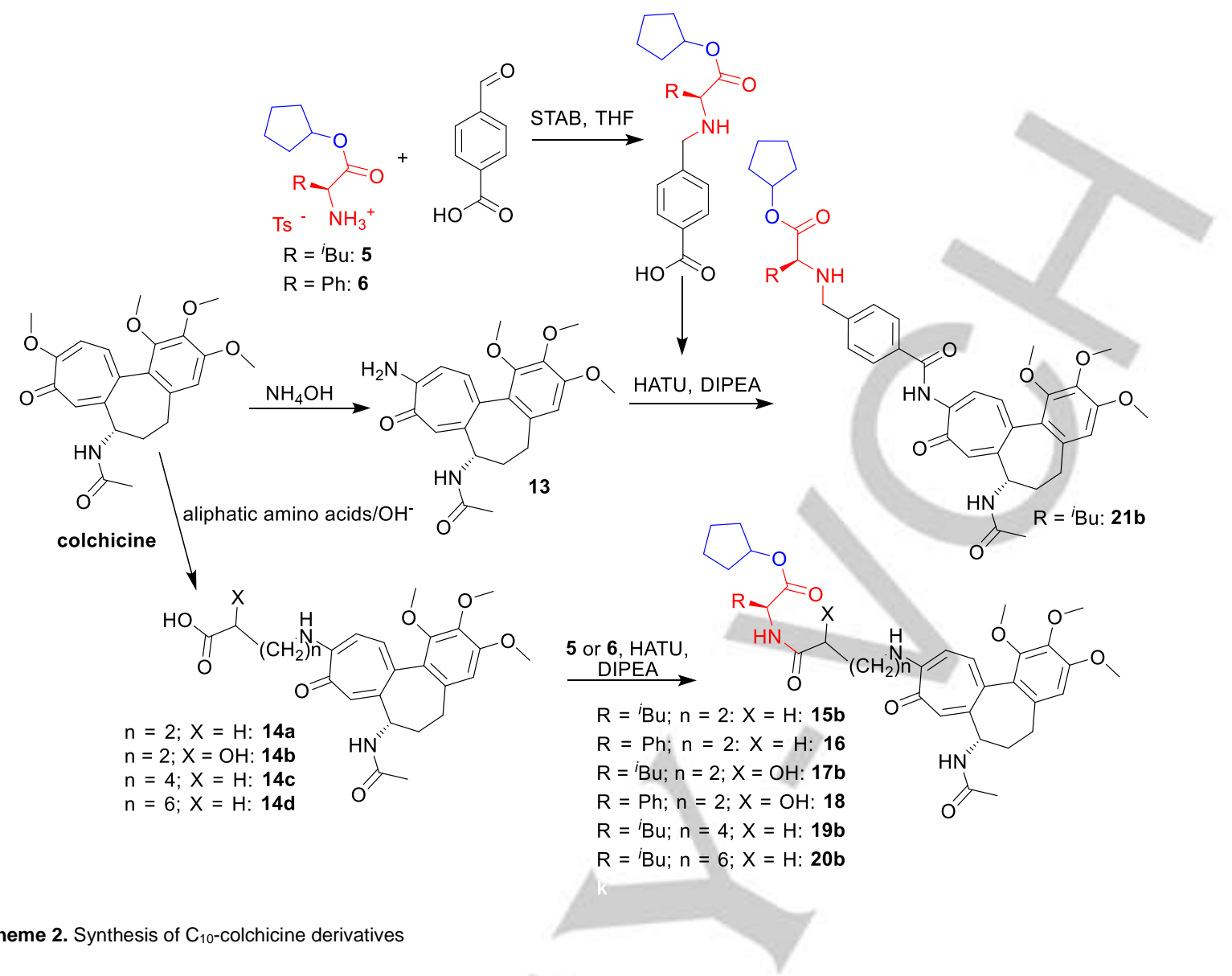

\section{Cytotoxicity assay}

Cytotoxicity of the studied compounds was evaluated via Cell Titer Blue assay in HeLa and Huh7 cell lines over periods of 24 and $72 \mathrm{~h}$. Attempts to measure the cytotoxicity in a $24 \mathrm{~h}$ assay did not show the full cytotoxic effect of combretastatin, colchicine and its derivatives.

The main objective in creating prodrugs was to decrease the cytotoxicity of combretastatin and its derivatives. Indeed, all obtained derivatives show a cytotoxicity of at least three orders of magnitude lower than combretastatin A-4. The prodrug with a leucine cyclopentanol ester linked to combretastatin (7b) already shows a large decrease in toxicity with a $\mathrm{CC}_{50}$ at about $30 \mu \mathrm{M}$. If there is a spacer with a length of four carbon atoms (4aminobutyric acid) inserted between combretastatin and the hCE1-sensitive motif (8b), the compounds become slightly more toxic, perhaps due to higher permeability or stability. However, the analogue with a $\mathrm{C}_{8}$-spacer $(\mathbf{9 b})$ shows reduced toxicity. We observed the same characteristics with the phenylglycine cyclopentanol esters 10, 11 and 12.

Analysis of the data of colchicine derivatives obtained in $72 \mathrm{~h}$ treatment period shows that all 10 -aminocolchicine derivatives appear at least 100 times less toxic in comparison to the initial 10 -aminocolchicine and colchicine. These data correlate very well with the results obtained by other researchers that demonstrated lower toxicity of the 10-alkylaminocolchicine derivatives as compared to 10-aminocolchicine and colchicine. ${ }^{[39,40]}$
In conclusion, the aim of reduced toxicity was achieved by creation of prodrugs for colchicine and combretastatin.

Tubulin polymerization inhibition by combretastatin and colchicine derivatives and its correlation with antiviral activity

The antiviral activity against DENV was measured after a $24 \mathrm{~h}$ incubation period with compound concentrations that allowed cell viabilities greater than $80 \%$. However, after $72 \mathrm{~h}$ incubation, cytotoxicity was observed in the nanomolar concentration range for the initial compounds (colchicine, combretastatin) and in the micromolar range for the derivatives Along with the cytotoxicity, the ability of these compounds to inhibit the polymerization of tubulin drops with increasing length of the spacer. At a concentration of $10 \mu \mathrm{M}$, prodrug $7 \mathrm{~b}$ leads to a tubulin polymerization grade of $88 \%$ compared to the DMSO control (Table 1). Prodrug $\mathbf{8 b}$ with the 4-aminobutyric acid spacer showed almost no inhibition (95\% polymerization grade), while the most bulky prodrug $9 \mathrm{~b}$ seems to promote tubulin polymerization. Although this compound might act as microtubule-stabilizer like paclitaxel, it is more likely that it either leads to precipitation of tubulin or precipitates itself and thereby generated a false positive signal in the tubulin polymerization assay. 
Table 1. Combretastatin and colchicine derivatives: Effect on tubulin polymerization, cytotoxicity and susceptibility to hCE1 catalysed hydrolysis.

\begin{tabular}{|c|c|c|c|c|c|}
\hline \multirow{2}{*}{ Compound } & \multirow{2}{*}{ Structure } & \multirow{2}{*}{$\begin{array}{l}\text { Tubulin } \\
\text { polymerization } \\
\text { at } 10 \mu \mathrm{M}, \%\end{array}$} & \multicolumn{2}{|c|}{$\mathrm{CC}_{50}(72 \mathrm{~h}), \mu \mathrm{M}$} & \multirow{2}{*}{$\begin{array}{l}\text { hCE1 catalysed cleavage in } \\
\text { vitro, } \%\end{array}$} \\
\hline & & & HeLa & Huh7 & \\
\hline DMSO & & 100 & - & - & \\
\hline $\begin{array}{l}\text { Combretastatin } \\
\text { A-4 }\end{array}$ & & $40 \pm 4$ & $0.003 \pm 0.001$ & $0.009 \pm 0.002$ & n.a. \\
\hline 2 & & $91 \pm 2$ & $>50$ & $>50$ & n.a. \\
\hline $7 a$ & & $88 \pm 2$ & $63.99 \pm 1.68$ & $>50$ & n.a. \\
\hline $7 \mathrm{~b}$ & & $88 \pm 5$ & $39.67 \pm 1.45$ & $26.05 \pm 2.45$ & $63.32 \pm 2.11$ \\
\hline $8 \mathbf{a}$ & & $84 \pm 8$ & $>50$ & $>50$ & n.a. \\
\hline $8 b$ & & $95 \pm 2$ & $0.92 \pm 0.63$ & $14.99 \pm 1.73$ & $68.16 \pm 3.24$ \\
\hline $9 a$ & & $112 \pm 5$ & $26.65 \pm 2.59 \mu \mathrm{M}$ & $>50$ & n.a. \\
\hline $9 b$ & & $142 \pm 22$ & $5.07 \pm 4.16$ & $22.04 \pm 1.55$ & $38.11 \pm 4.64$ \\
\hline 10 & & $79.4 \pm 1.0$ & $6.83 \pm 2.23$ & $8.52 \pm 1.54$ & 0 \\
\hline 11 & & $60 \pm 2$ & $0.95 \pm 0.72$ & $4.60 \pm 1.26$ & 0 \\
\hline 12 & & $93 \pm 6$ & $>50$ & $11.39 \pm 1.66$ & 0 \\
\hline Colchicine & & $22 \pm 8$ & $0.058 \pm 0.004$ & $0.003 \pm 0.002$ & n.a. \\
\hline 13 & & $33 \pm 2$ & $0.007 \pm 0.005$ & $0.008 \pm 0.004$ & n.a. \\
\hline $15 a$ & & $106 \pm 4$ & $>50$ & $>50$ & n.a. \\
\hline
\end{tabular}




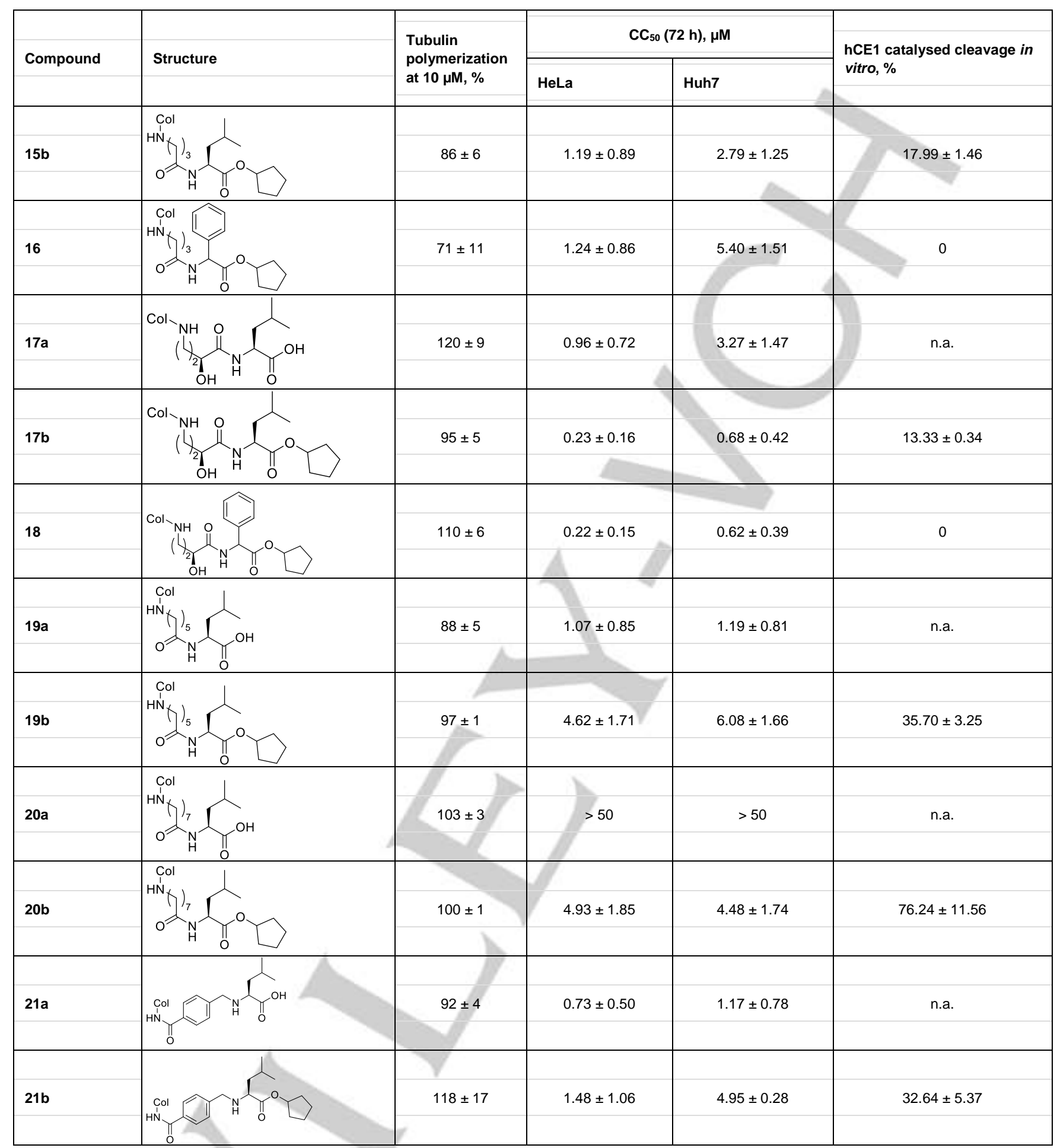

Conditions for the tubulin polymerization assay: $4 \mathrm{mg} / \mathrm{mL}$ tubulin, $1 \mathrm{mM} \mathrm{GTP}, 10 \mu \mathrm{M}$ compound, $80 \mathrm{mM}$ PIPES, pH 6.9, $0.5 \mathrm{mM} \mathrm{EGTA}, 2 \mathrm{mM} \mathrm{MgCl} 2,1 \mathrm{~h}$, $37^{\circ} \mathrm{C}$, given is the degree of polymerization compared to the DMSO blank $(100 \%=$ no inhibition). All experiments were performed in triplicate.

Hydrolysis assay: [hCE1] $=100 \mathrm{nM}$, [compound] $=10 \mu \mathrm{M}$ in phosphate buffer, $\mathrm{pH} 7.4$, incubated for $2 \mathrm{~h}$ at $37^{\circ} \mathrm{C}$ (if no cleavage was observed under these conditione, then the incubation was repeated for $24 \mathrm{~h}$ ). All experiments performed in triplicate.

"Com" = Combretastatin residue; "Col" = Colchicine residue; "n.a." = not applicable (i.e., molecule has no cleavage site)

The same correlation between the length of the spacer and the potency to inhibit tubulin polymerization is observed with the phenylglycine cyclopentanol esters 10, 11 and 12. Yet, these compounds show overall higher polymerization inhibition, with 11 being the most active one, reducing the rate of tubulin polymerization to $60 \%$. After hydrolysis, the toxicity of the hydrolyzed peers 7a, 8a and 9a is lower than in their precursors, perhaps because of pharmacokinetic effects, such as lower permeability of the carboxylate.

The hydrolyzed prodrugs show similar effects on tubulin polymerization as their precursors. For the pair $\mathbf{8} \mathbf{a} / \mathbf{b}$, a moderate increase in activity could be found after hydrolysis. Nevertheless, 
the concept of intracellular prodrug cleavage by ester hydrolysis does not require an increase of activity, because the hydrolyzed carboxylate drug can be anticipated to have low passive membrane permeability and thereby accumulate in the target cell.

The hydrolyzed analogues of the colchicine prodrugs with shorter spacers like $Y$-amino- $\beta$-hydroxybutyric and $Y$ aminobutyric acid are less active in the tubulin polymerization assay than the respective prodrugs, possibly because of higher polarity of the residue in position 10 as compared to other colchicine derivatives. This property is probably not compatible with binding to hydrophobic regions in the colchicine-binding site. The only colchicine derivative for which its hydrolyzed peer has shown higher inhibitory activity on tubulin polymerization than the initial prodrug was compound $\mathbf{2 1} \mathbf{b}$. In this case the polarity of the carboxylic group in the motif is counterbalanced by the nonpolar aromatic ring.

Table 2. Antiviral activity in Huh7-cells against DENV or ZIKV. Given is either the virus titre reduction in $\%$ at a certain concentration or the concentration where virus titre was reduced by $50 \%\left(\mathrm{EC}_{50}\right)$, determined after an exposure time of $24 \mathrm{~h}$. Also, for the sake of comparison the $\mathrm{CC}_{50}$ in Huh7 cells at $24 \mathrm{~h}$ is provided.

\begin{tabular}{|c|c|c|c|}
\hline Compound & Structure & $\begin{array}{l}C_{50} \\
(24 \mathrm{~h}), \\
\mu \mathrm{M}, \text { Huh7 }\end{array}$ & $\begin{array}{l}\text { Virus titre } \\
\text { reduction }\end{array}$ \\
\hline $\begin{array}{l}\text { Combreta- } \\
\text { statin A-4 }\end{array}$ & & 38.30 & $\begin{array}{l}\text { DENV: } \\
\text { EC } 50=870 \mathrm{nM} \\
\text { ZIKV: } 70 \% \text { at } \\
5 \mu \mathrm{M}\end{array}$ \\
\hline Colchicine & & 29.91 & $\begin{array}{l}\text { DENV: } \\
\text { EC } 50=150 \mathrm{nM} \\
\text { ZIKV: } 89.67 \% \text { at } \\
5 \mu \mathrm{M}\end{array}$ \\
\hline 13 & & 16.84 & $\begin{array}{l}\text { DENV: } 37.04 \% \\
\text { at } 0.78 \mu \mathrm{M}\end{array}$ \\
\hline $17 b$ & & 32.54 & $\begin{array}{l}\text { ZIKV: } \\
\mathrm{EC}_{50}=878 \mathrm{nM}\end{array}$ \\
\hline $19 b$ & & 16.25 & $\begin{array}{l}\text { DENV: } 20.00 \% \\
\text { at } 3.125 \mu \mathrm{M}\end{array}$ \\
\hline $20 b$ & $\begin{array}{c}\text { Col } \\
1 \\
H N\end{array}$ & 8.95 & $\begin{array}{l}\text { DENV: } 40.00 \% \\
\text { at } 3.125 \mu \mathrm{M}\end{array}$ \\
\hline $21 b$ & & 10.98 & $\begin{array}{l}\text { DENV: } 52.94 \% \\
\text { at } 0.78 \mu \mathrm{M} \\
\text { ZIKV: } \\
\text { EC }_{50}=1.851 \mu \mathrm{M}\end{array}$ \\
\hline
\end{tabular}

"Com" = Combretastatin residue; "Col" = Colchicine residue

The fact that toxicity and activity of the microtubule disrupting agents have been assayed in tumour cell lines might bring one artefact interaction that would be avoided in healthy cells. Thus, the possible interaction of the obtained compounds with the membrane-bound P-glycoprotein (P-gp, ABCB1, MDR1), which is overexpressed in several different tumour types and is associated with poor response to chemotherapy (various microtubule disrupting compounds are substrates for P-gp, and colchicine is one of them), might be one of the effects that could influence the cell viability and antiviral response. However, it has been detected before ${ }^{[53]}$ that minimal size of the colchicine derivative molecule is important for the interaction with P-gp, which means that derivatization with bigger substituents can affect it. According to Tang-Wai et al. ${ }^{[53]}$ presence of rings $B$ and $C$ is also crucial, which means that colchicine's biphenyl analogues, like combretastatin, lack this interaction.

Combretastatin, colchicine and some of the colchicine derivatives were tested on their antiviral activity against dengue and Zika virus (Table 2). The activity $\left(E_{50}\right)$ of combretastatin and colchicine against dengue replication was $870 \mathrm{nM}$, and $150 \mathrm{nM}$, respectively. The colchicine prodrug 21b showed considerable antiviral activity despite its marginal effect on tubulin polymerization, possibly due to an effect on microtubule dynamics or due to interactions with other host cellular or viral mechanisms. hCE1

Hydrolysis of combretastatin and colchicine derivatives by

The active site cavity of hCE 1 is very large $\left(\sim 1300 \AA^{3}\right.$ in volume), mostly flexible and is lined mainly by hydrophobic residues, with the exception of the catalytic triad. The enzyme is therefore considered to be relatively promiscuous and capable of interacting with a variety of diverse ligands ${ }^{[54]}$ preferring those with small alcoholic group and a bulky acyl group, such as oseltamivir, clopidogrel ${ }^{[55]}$ and enalapril. ${ }^{[56]}$

Nevertheless, a clear structure-cleavability-relationship for hCE1 substrates is observed in the present study. All combretastatin prodrugs that contain the leucine cyclopentyl moiety were hydrolyzed by the carboxyl esterase (Table 1). High resolution ESI mass spectrometry detected the resulting carboxylic acids and the ratio of hydrolyzed prodrug was quantified by HPLC-UV. The conversion was less effective for derivatives containing a long alkyl spacer. The 8-aminooctanoic acid analogue $(\mathbf{9 b})$ had the lowest ratio of cleavage. This might be due to steric hindrance by the $\mathrm{C}_{8}$-chain. The prodrugs with a 4-aminobutyric acid based spacer and with no spacer at all were cleaved more effectively. Conversion rates after $1 \mathrm{~h}$ of incubation were between $60-70 \%$.

On the other hand, all phenylglycine cyclopentyl ester combretastatins were inert against hydrolysis by hCE1. This contradicts the results by Needham et al. ${ }^{[22]}$ who presented the phenylglycine cyclopentyl moiety as an hCE1 sensitive motif. After incubation, no cleavage products could be detected by HPLC-UV or ESI-MS.

Out of all colchicine derivatives with esterase-sensitive motifs tested for cleavability, only those containing leucine cyclopentyl ester were hydrolyzed by hCE1. In the row of derivatives with spacers ranging from $\gamma$-aminobutyric acid to $\varepsilon$ aminocaproic acid and 8-aminooctanoic acid the average conversion rate increased from $17.99 \pm 1.46 \%$ to $35.70 \pm$ $3.25 \%$ and $76.24 \pm 11.56 \%$, respectively. Hydrolysis could not be observed for the phenylglycine cyclopentyl esters moieties. As for the combretastatin analogues, the lack of hydrolysis of the 
phenylglycine cyclopentyl ester by hCE1 is in conflict with the data presented by Needham et al..[2]

Considering this conflicting evidence, we studied whether compounds with the Phg-Cyp motif inhibit the hydrolytic activity of hCE1. Compounds 10, 11, 12 and 18 were therefore assayed for inhibition of hCE1 activity. However, these compounds did not reduce the hydrolysis of the substrate $p$-nitrophenyl acetate by hCE1.

Another possible reason for the lack of derivatives' hydrolysis was the inability of their ester moieties to enter the hydrolytic site of the enzyme, which could have been caused by racemization of the Phg that has been previously detected in similar conditions of solid-phase peptide synthesis ${ }^{[57]}$ or steric hindrance as it could be in the case of tert-Bu derivatives. ${ }^{[21]}$ However, one of the stereoisomers should still fit the enzyme hydrolytic pocket and, at least, partial hydrolysis should take place. Only 4-formylbenzoic acid based spacer in colchicine derivatives gave the prodrugs that are inactive before cleavage and get activated after cleavage. Introduction of alkyl spacers resulted in compounds with good inhibition of tubulin polymerisation in uncleaved form lower inhibition in cleaved form. Remaining uncleaved and active these compounds cannot be classified as prodrugs but only as active compounds.

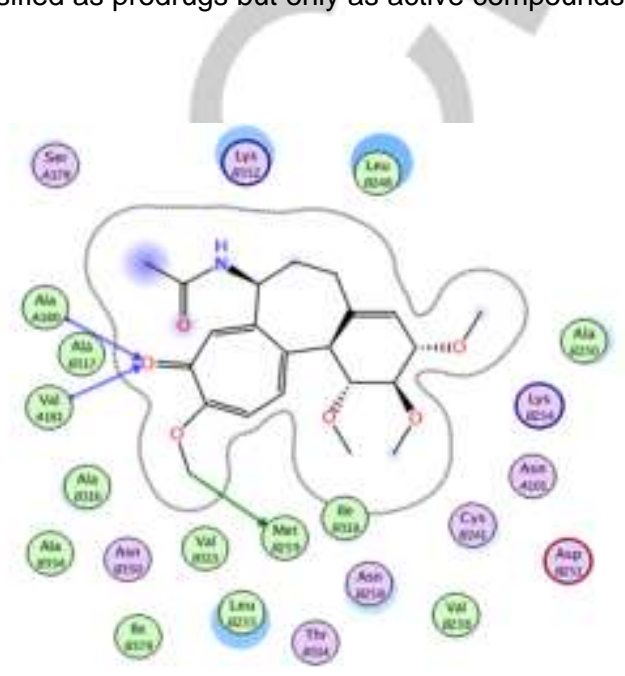

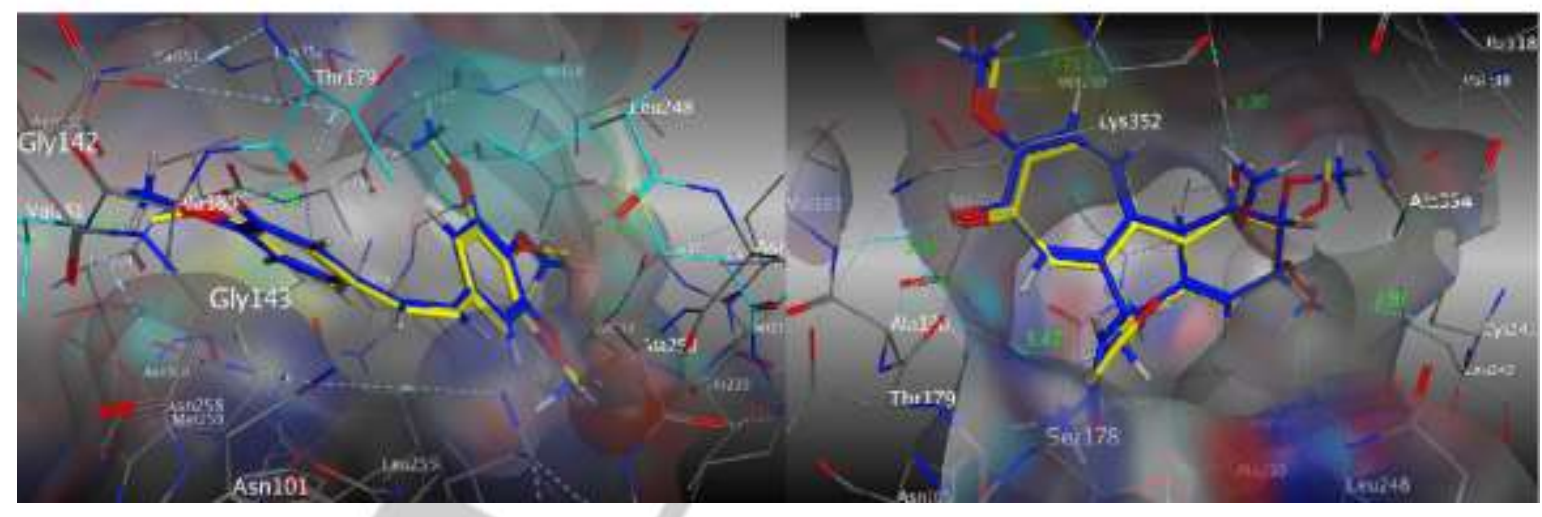

Figure 4. 2D diagram (ligand interactions) and 3D interactions with the tubulin binding site for Col (right) and Com (left). Blue shows the position of ligands taken from crystalline PDB data; $4 \mathrm{O} 2 \mathrm{~B}$ and $5 \mathrm{LYJ}$.

\section{Molecular modelling studies}

To rationalize the binding mode of the compounds, docking of some of them was performed in the colchicine binding site of tubulin. Initially, the parent compounds combretastatin (Com) and colchicine $(\mathrm{Col})$ were docked into the colchicine binding site of tubulin to validate the docking procedure.

The protonated ligand structures were optimized within the binding site in the crystal structure of tubulin (PDB; 4O2B-for the Col derivatives ${ }^{[58]}$ and 5 LYJ for the Com derivatives $\left.{ }^{[25]}\right)$. In the process of docking, the active site around the bound inhibitor in the molecular structure of tubulin was determined with the radius of $8 \AA$. Values of free energies of binding between the protein and the ligand were calculated taking into account the contributions of hydrogen bonds, as well as ionic, hydrophobic and van der Waals interactions.

The predicted energies of binding between the protein and Col or Com were $16.84 \mathrm{kcal} / \mathrm{mol}$ and $15.12 \mathrm{kcal} / \mathrm{mol}$, respectively, which is in accordance with their inhibiting effect on the polymerization of tubulin. The best docking positions for Col (right) and Com (left) with amino acid residues of the active site are shown in Figure 4.

The performed docking calculations are in agreement with the experimental $x$-ray structures. This indicates a correct choice of parameters for docking and the force field calculations. Let us briefly consider some features of the interaction of the base molecules Com and Col that is important for further analysis of the results of docking in regard of their derivatives. As can be seen from the results of docking, both molecules bind to the colchicine binding site via hydrogen bonds and hydrophobic 
interactions. The molecule $\mathrm{Col}$ is orientationally fixed in a hydrophobic pocket consisting of Val181a (3.05 $\AA$ ) and Ala180a (3.26 $\AA$ ). The stabilization of the Col molecule is due to the $\mathrm{H}$ acceptor interaction with the carbonyl group of the sevenmembered ring of colchicine. The $\mathrm{H}$-donor interaction is observed between the amino acid residues Met259 $\beta$ (3.71 $\AA$ ), Thr179a (3.47 $\AA$ ) and the methoxytropone ring. 3- and 4- $\mathrm{OCH}_{3}$ methoxyphenyl can form hydrogen bonds with Cys241 $\beta$ (3.56 and $4.68 \AA$ ).

Com binding also occurs in the colchicine binding site of tubulin, with the only difference that amino acid residues taking part in the formation of the ligand-protein complex are a bit different (See Figure 4 below). The molecule Com is loosely located in the pocket of tubulin and forms strong hydrophobic interactions with residues Leu248 $\beta$, Ala354 $\beta$ and Val181 $\alpha$ of the active centre of the protein. As seen from Figure 4, the strong binding of compounds to the protein determines their inhibiting activity as to the polymerization of tubulin that corresponds to the experimental results of the studies on the inhibition of tubulin polymerization.

The next step in molecular modelling was to study the binding mode of the Com and Col derivatives to tubulin. To this end, we examined the docking of the molecules $8 \mathrm{a}, \mathbf{1 7 a}$ and $21 \mathrm{a}$ which are representatives of the synthesized series of the Com and Col basic structures, to the colchicine-binding site of tubulin.

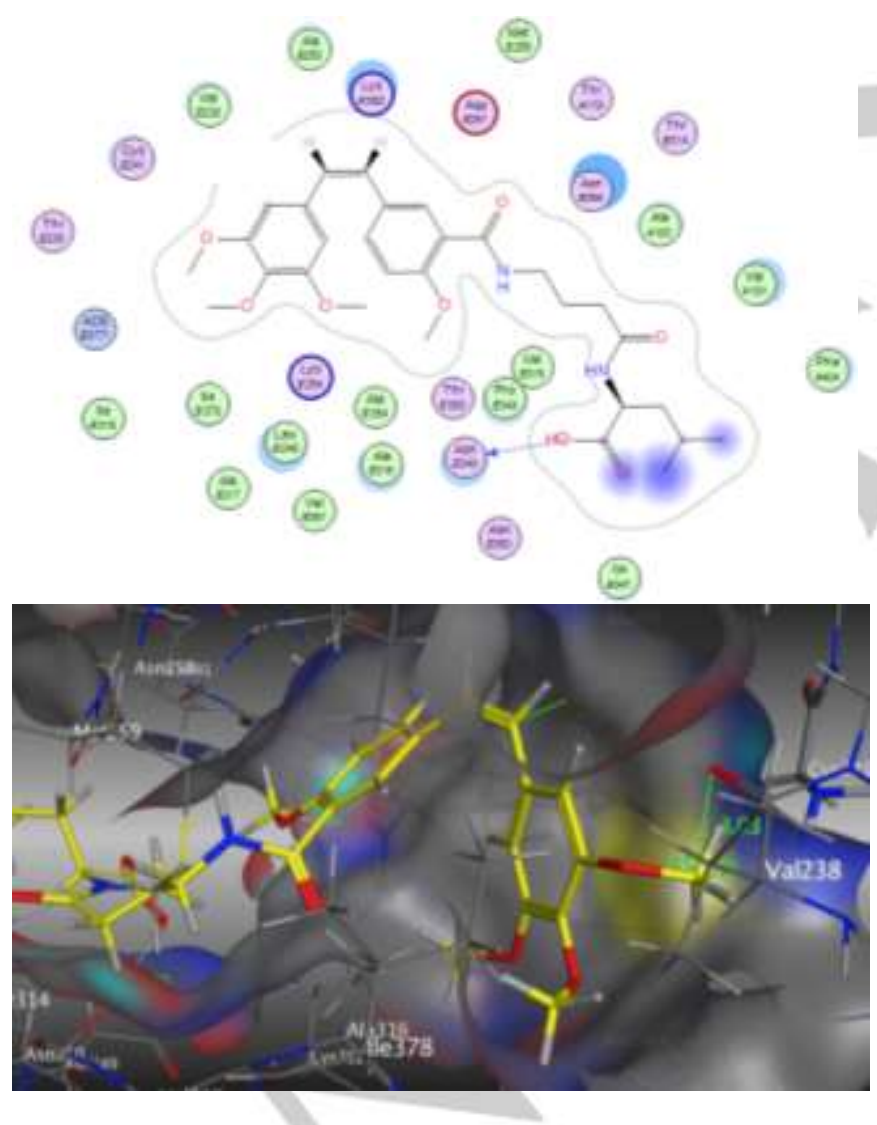

Figure 5. 2D diagram and $3 \mathrm{D}$ interactions with the tubulin-binding site for $\mathbf{8 a}$

The increase in size and volume of the molecule directly affects the character of binding to the receptor. Figure 5 presents a 2D-diagram and the $3 \mathrm{D}$ arrangement of molecules bound to the colchicine-binding site of tubulin. As can be seen from Figure 5, several binding interactions different from Com appear between the Com derivative $\mathbf{8} \mathbf{a}$ and the amino acid residues of the active site. For example, the formation of a strong hydrogen bond between $A s n 349 \beta$ (2.27 $\AA$ ) and the hydroxyl group is observed in the 4-aminobutyric acid fragment.

At the opposite end of the molecule, a new close contact appears between the 3-methoxy group of $\mathbf{8 a}$ and the carbonyl group of Cys $241 \beta(2.75 \AA)$ and Val238 $\beta(3.03 \AA)$. It should be noted that the interaction with the receptor occurs predominantly through the $\beta$-subunit of the protein. Hydrophobic interactions of the molecule at distances from 3.47 to $3.95 \AA$ arise with Lys $352 \beta$, Ala354 $\beta$, Thr179 $\alpha$ and Val181 $\alpha$. The predicted binding energy of $8 \mathbf{a}$ with the target is $10.37 \mathrm{kcal} / \mathrm{mol}$, considerably lower than for Com. This suggests a weaker interaction of $8 \mathbf{a}$ with the target.

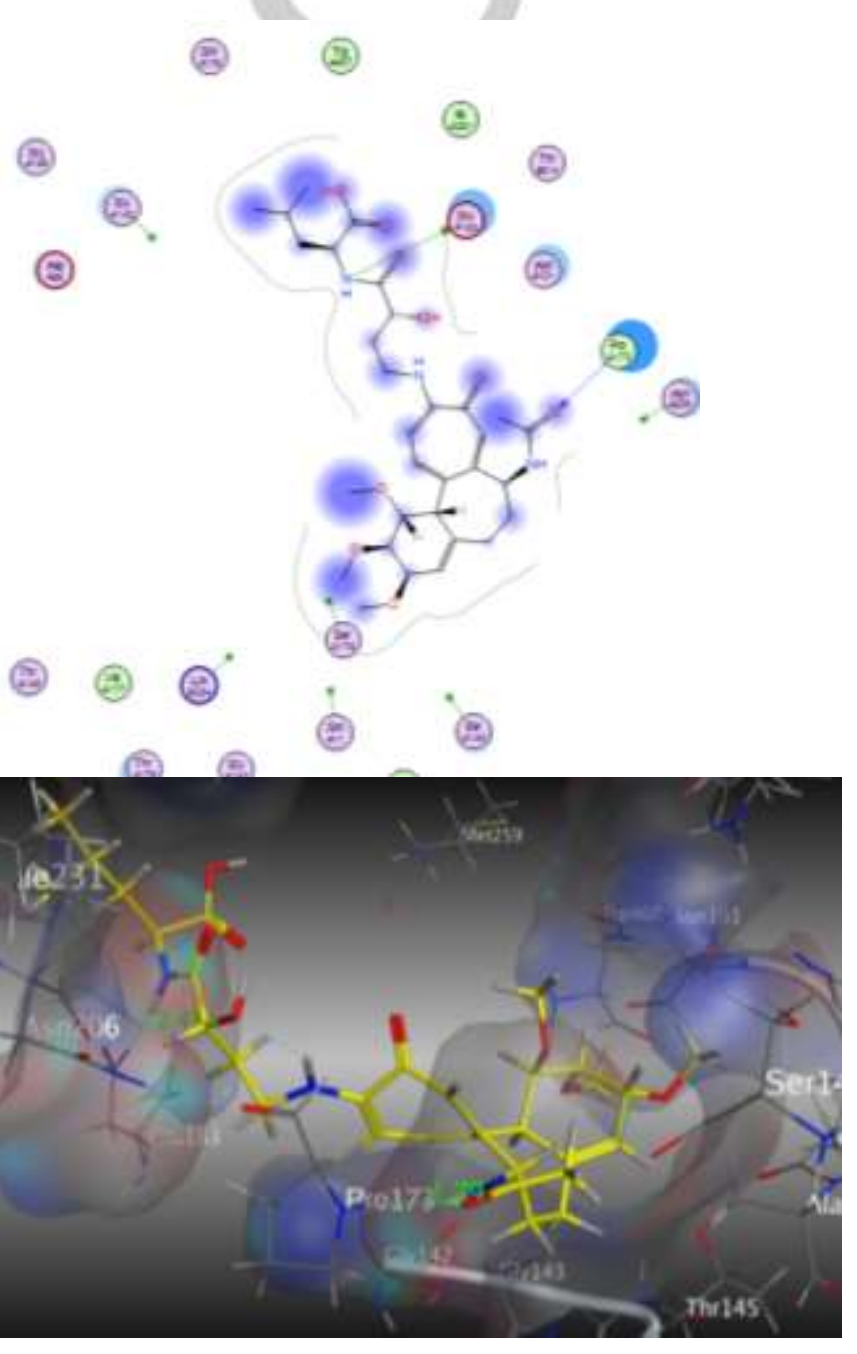

Figure 6. 2D diagram and 3D interactions with the tubulin binding site for 17 a

The results of docking of the Col derivative 17a compound are shown in Figure 6. As seen from the 2D diagram, the molecule forms several hydrogen bonds with the target. The strongest interaction is observed for Glu183a (2.41 $\AA$ ) and Pro173a $(1.79 \AA)$. Similar to $8 \mathbf{a}$, the main contributions to the binding arise from the terminal parts of the molecule (4aminobutyric acid and 3,4,5-trimethoxiphenyl-methoxytropone ring). Formation of the hydrogen bond Pro173a with the 
acetamide group of the seven-membered ring is characteristic for $17 a$.

The linker $\left(-\mathrm{CH}_{2}-\right)_{\mathrm{n}}$ attached to the acetamide group does not radically affect the character of binding of the root (head) part of the molecule ( $\mathrm{Col}$ and $\mathrm{Com}$ ) to the active site of the protein. Differences are observed in the spatial arrangement of these molecules in the receptor pocket and in their specific binding to the amino acids of the protein. All this leads to a decrease in predicted energy of binding to the target for $17 \mathrm{a}(11.27 \mathrm{kcal} / \mathrm{mol})$, compared to the unsubstituted molecule ( $\mathrm{Col}-16.84 \mathrm{kcal} / \mathrm{mol})$.

The exit of a bulk molecule from the colchicine-binding site can be one of the factors reducing the inhibitory activity of the molecule as to the tubulin polymerization, and in some cases (see 9a and 17a) it can even accelerate its polymerization. The introduction of the phenyl group into the base molecule as a linker is illustrated by the example of the Col derivative 21a. The docking pose of 21a in the binding site of tubulin is shown in Figure 7.
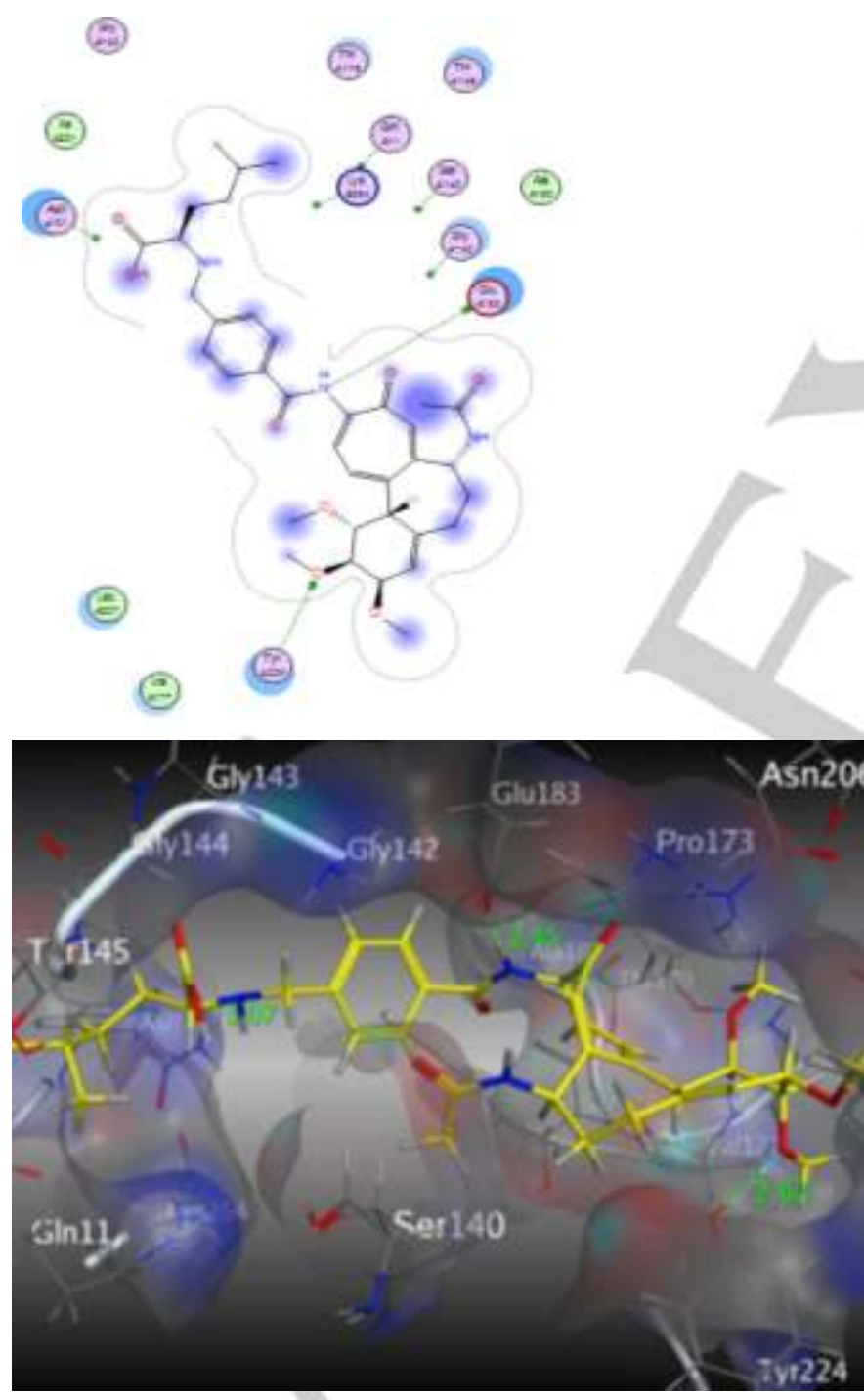

Figure 7. 2D diagram and 3D interactions with the tubulin binding site for 21a.

As in the case of $17 \mathrm{a}$, the $\mathrm{H}$-acceptor interactions of the amide group (-NH-) with Glu183a $(2.45 \AA)$ and of the $4-\mathrm{OCH}_{3}$ groups with Tyr224a $(2.62 \AA)$ are observed for 21a. The hydrogen bond formation with participation of the amide fragment is characteristic for most compounds exhibiting biological activity. The aromatic ring does not participate in direct binding to the receptor.

On the other hand, as noted above, the linker can significantly affect the spatial orientation of a ligand. Due to the presence of the conformationally flexible alkyl linkers - $\left(\mathrm{CH}_{2}-\right)_{n}$ the possibility of changing the spatial orientation of the head ( $\mathrm{Col}$ and Com) and tail (4-aminobutyric acid) of the molecule increases significantly (see $\mathbf{8 a}, \mathbf{9 a}$, and $\mathbf{1 7 a}$ ). The addition of the 'hard' phenyl ring to the Col molecule makes the 21a compound more flat and stiff, due to the presence of the stabilizing $\pi$-bonds in the Col-NH-CO-Ph fragment. The predicted energy of binding with the target for both $21 \mathrm{a}$ and $17 \mathrm{a}$ amounts to $11.25 \mathrm{kcal} / \mathrm{mol}$, and is significantly lower than for Col.

In conclusion, it should be noted that the Col and Com derivatives obtained in this work form less interactions with the colchicine binding site of tubulin and inhibit the polymerization of the protein to a lesser extent. At the same time, they are less toxic, compared to non-substituted Col and Com.

\section{Conclusions}

The main pharmacological property and disadvantage of the TPIs regarding their use for antiviral therapy is their high cytotoxicity. As a result of the designed modifications in the structure of two TPIs, colchicine and combretastatin, a group of less toxic derivatives with an hCE1 sensitive motif in their structure was obtained. It could be demonstrated that only Leubased derivatives were subjected to hydrolysis by hCE1 whereas the Phg-containing analogues remained uncleaved, contrary to the findings of Needham et al. ${ }^{[22]}$ The Leu- and Phgbased derivatives were less cytotoxic than their parent compounds colchicine and combretastatin. Docking studies of the compounds within the colchicine-binding site of tubulin indicated several reasons for the lower affinity towards tubulin. The most active compounds in viral replication assays were the parent compounds colchicine and combretastatin, but some derivatives like 21b and 17b also showed good activity while being much less toxic. The lack of correlation between tubulin binding, cytotoxicity and the antiviral activity of the initial compounds and their derivatives indicates that tubulin binding is not the only mechanism of antiviral activity of the latter. Moreover, the lack of significant difference between the cytotoxicity of cleavable and non-cleavable compounds indicates that the hCE1 selective motif does not influence the toxicity. Further exploration of this topic could elucidate alternative mechanisms of antiviral activity of the obtained derivatives besides tubulin binding.

\section{Experimental Section}

Chemistry. All chemicals for the synthesis were of analytical grade and purchased from Sigma-Aldrich (Germany), Carbolution (Germany), TCl (Belgium), Carl Roth GmbH (Germany), and Acros Organics (Belgium) Chemicals were used without further purification unless otherwise stated. All solvents were purchased from commercial sources. Dry solvents were stored over molecular sieves. NMR spectra were recorded on a Varian NMR instrument at $300 \mathrm{MHz}, 298 \mathrm{~K}$ in $\mathrm{CDCl}_{3}, \mathrm{CD}_{3} \mathrm{OD}$ or DMSO-d6. 
Chemical shifts $(\delta)$ are given in parts per million (ppm). Proton peaks of residual non-deuterated solvents were used for calibration. Coupling constants $(\mathcal{J})$ are given in Hertz $(\mathrm{Hz})$. Multiplicity is given as s (singlet), d (doublet), $\mathrm{t}$ (triplet), $\mathrm{q}$ (quartet) or $\mathrm{m}$ (multiplet). Mass spectra were measured on a Bruker micrOTOF-Q II (HR-ESI) instrument. Flash chromatography was performed on a Biotage Isolera One purification system using silica gel $(0.060-0.200 \mathrm{~mm})$ cartridges (KP-Sil) and UV monitoring at $254 \mathrm{~nm}$ and $280 \mathrm{~nm}$. Preparative HPLC was performed on an ÄKTA Purifier, GE Healthcare (Germany), with an RP-18 pre and main column (Reprospher, Dr. Maisch GmbH, Germany, C18-DE, $5 \mu \mathrm{M}$, $30 \mathrm{~mm} \times 16 \mathrm{~mm}$ and $120 \mathrm{~mm} \times 16 \mathrm{~mm}$ ). Analytical HPLC was performed on an Agilent 1200 HPLC system with a UV detector on an RP-18 column (ReproSil-Pur-ODS-3, Dr Maisch GmbH, Germany, $3 \mu \mathrm{m}, 50 \mathrm{~mm}$ x $2 \mathrm{~mm})$.

Synthesis of $1.3 \mathrm{~g}(15.3 \mathrm{mmol}, 1 \mathrm{eq}) 3,4,5$-trimethoxybenzaldehyde were dissolved in $50 \mathrm{~mL}$ methanol. $1.17 \mathrm{~g}(30.6 \mathrm{mmol}, 2 \mathrm{eq}) \mathrm{NaBH}_{4}$ were added in portions. The solution was stirred for 30 minutes at room temperature. Upon completion, the solvent was removed under reduced pressure and the residue was dissolved in dichloromethane, washed with water, dried over $\mathrm{MgSO}_{4}$ and concentrated in vacuo. Yield $2.44 \mathrm{~g}$ (12.32 mmol, 81\%). ${ }^{1} \mathrm{H} \mathrm{NMR}\left(\mathrm{CDCl}_{3}\right): \delta=6.61(\mathrm{~s}, 2 \mathrm{H}), 4.64(\mathrm{~d}, J=4.4$ Hz, 2 H), 3.87 (s, $6 \mathrm{H}), 3.84(\mathrm{~s}, 3 \mathrm{H}), 1.64(\mathrm{t}, J=4.4 \mathrm{~Hz}, 1 \mathrm{H})$.

$2.4 \mathrm{~g}$ (3,4,5-trimethoxyphenyl)methanol were dissolved in $100 \mathrm{~mL}$ dichloromethane and cooled to $0^{\circ} \mathrm{C}$. $1.25 \mathrm{~mL}$ (13.3 mmol, 1.1 eq) $\mathrm{PBr}_{3}$ were added dropwise. The solution was stirred for 30 minutes. Upon completion, the reaction was quenched with ice-cold water and the product was extracted with dichloromethane. The combined organic extracts were dried over $\mathrm{MgSO}_{4}$ and concentrated in vacuo. Yield $2.7 \mathrm{~g}$ $(10.4 \mathrm{mmol}, 86 \%) .{ }^{1} \mathrm{H} \mathrm{NMR}\left(\mathrm{CDCl}_{3}\right): \delta=6.62(\mathrm{~s}, 2 \mathrm{H}), 4.46(\mathrm{~s}, 2 \mathrm{H}), 3.87$ (s, $6 \mathrm{H}), 3.84(\mathrm{~s}, 3 \mathrm{H})$.

In a round bottom flask, $2.7 \mathrm{~g}(10.4 \mathrm{mmol}, 1 \mathrm{eq})$ 3,4,5-trimethoxybenzylbromide and $2.7 \mathrm{~g}(10.4 \mathrm{mmol}, 1 \mathrm{eq}) \mathrm{PPh}_{3}$ were dissolved in chloroform. The solution was refluxed at $65^{\circ} \mathrm{C}$ for $24 \mathrm{~h}$. The solvent was removed under reduced pressure. The oily residue was collected in cyclohexane and evaporated again, yielding a white solid. The crude product was purified by recrystallization in $\mathrm{EtOH}$. Yield $5.4 \mathrm{~g}(10.4 \mathrm{mmol}$, 100\%). ${ }^{1} \mathrm{H} \mathrm{NMR}\left(\mathrm{CDCl}_{3}\right): \delta=7.80-7.73(\mathrm{~m}, 9 \mathrm{H}), 7.66-7.62(\mathrm{~m}, 6 \mathrm{H}), 6.46$ $(\mathrm{d}, J=2.7 \mathrm{~Hz}, 2 \mathrm{H}), 5.40(\mathrm{~d}, J=13.9 \mathrm{~Hz}, 2 \mathrm{H}), 3.76(\mathrm{~s}, 3 \mathrm{H}), 3.51(\mathrm{~s}, 6 \mathrm{H})$

General procedure for Wittig reaction of combretastatin A-4 and 2. In a dry and nitrogen-purged round bottom flask, $500 \mathrm{mg}(0.955 \mathrm{mmol}$, 2 eq) 1 were suspended in $10 \mathrm{~mL}$ dry THF and cooled to $0^{\circ} \mathrm{C}$. $955 \mu \mathrm{L}$ (2.38 mmol, 5 eq) of a $2.5 \mathrm{M} \mathrm{n}$-butyllithium solution in hexane were added dropwise. The suspension should maintain an orange colour for at least 30 minutes. Then, the corresponding benzaldehyde $(0.477 \mathrm{mmol}$, 1 eq) was added in one portion. The reaction mixture was allowed to warm to room temperature and stirred overnight. Upon completion, the reaction was quenched with ice-cold water. The aqueous phase was neutralized with $1 \mathrm{M} \mathrm{HCl}$ and the product was extracted three times with ethyl acetate. The combined organic extracts were dried over $\mathrm{MgSO}_{4}$ and evaporated to give the crude product that contained the cis- and the trans-isomer. The desired cis-product (combretastatin A-4) or a mixture of cis- and trans-product respectively (2) was isolated by flash chromatography $(10 \%-60 \%$ ethyl acetate in cyclohexane for combretastatin A-4 and $10 \%$ methanol in ethyl acetate for 2 respectively).

Combretastatin A-4. Yield $56 \mathrm{mg}(0.177 \mathrm{mmol}, 37 \%) .{ }^{1} \mathrm{H} \mathrm{NMR}\left(\mathrm{CDCl}_{3}\right)$ : $\delta=6.92(\mathrm{~d}, J=1.8 \mathrm{~Hz}, 1 \mathrm{H}), 6.79(\mathrm{dd}, J=8.3 \mathrm{~Hz}, J=1.8 \mathrm{~Hz}, 1 \mathrm{H}), 6.73$ $(\mathrm{d}, J=8.3 \mathrm{~Hz}, 1 \mathrm{H}), 6.52(\mathrm{~s}, 2 \mathrm{H}), 6.47(\mathrm{~d}, J=12.1 \mathrm{~Hz}, 1 \mathrm{H}), 6.41(\mathrm{~d}, J=$ $12.1 \mathrm{~Hz}, 1 \mathrm{H}), 5.52(\mathrm{bs}, 1 \mathrm{H}), 3.86(\mathrm{~s}, 3 \mathrm{H}), 3.84(\mathrm{~s}, 3 \mathrm{H}), 3.70(\mathrm{~s}, 6 \mathrm{H})$. HRMS-ESI $(\mathrm{m} / \mathrm{z}):[\mathrm{M}+\mathrm{Na}]^{+}$calcd for $\mathrm{C}_{18} \mathrm{H}_{20} \mathrm{O}_{5} \mathrm{Na}: 339.1203$, found: 339.1210 .
2. Combined yield $96.6 \mathrm{mg}(0.281 \mathrm{mmol}, 59 \%) .{ }^{1} \mathrm{H}$ NMR $\left(\mathrm{CDCl}_{3}\right)$ : cisisomer: $\delta=8.15(\mathrm{~d}, 2.0 \mathrm{~Hz}, 1 \mathrm{H}), 7.45(\mathrm{dd}, J=8.8 \mathrm{~Hz}, J=2.0 \mathrm{~Hz}, 1 \mathrm{H})$, $6.89(\mathrm{~d}, J=8.8 \mathrm{~Hz}, 1 \mathrm{H}), 6.57(\mathrm{~d}, J=12.1 \mathrm{~Hz}, 1 \mathrm{H}), 6.50(\mathrm{~d}, J=12.1 \mathrm{~Hz}$, $1 \mathrm{H}), 6.45(\mathrm{~s}, 2 \mathrm{H}), 4.05(\mathrm{~s}, 3 \mathrm{H}), 3.85(\mathrm{~s}, 3 \mathrm{H}), 3.69(\mathrm{~s}, 6 \mathrm{H})$. trans isomer: $\delta=8.37(\mathrm{~d}, J=2.0 \mathrm{~Hz}, 1 \mathrm{H}), 7.68(\mathrm{dd}, J=8.6 \mathrm{~Hz}, J=2.0 \mathrm{~Hz}, 1$ $\mathrm{H}), 7.07(\mathrm{~m}, 1 \mathrm{H}), 7.06(\mathrm{~d}, J=16.6 \mathrm{~Hz}, 1 \mathrm{H}), 6.97(\mathrm{~d}, J=16.6 \mathrm{~Hz}, 1 \mathrm{H})$, $6.74(\mathrm{~s}, 2 \mathrm{H}), 4.11(\mathrm{~s}, 3 \mathrm{H}), 3.92(\mathrm{~s}, 6 \mathrm{H}), 3.87(\mathrm{~s}, 3 \mathrm{H}) . \mathrm{HRMS}-\mathrm{ESI}(\mathrm{m} / \mathrm{z})$ : $[\mathrm{M}+\mathrm{Na}]^{+}$calcd for $\mathrm{C}_{19} \mathrm{H}_{20} \mathrm{O}_{6} \mathrm{Na}: 367.1158$, found: 367.1186 .

General procedure for amide coupling of compounds $(3,4,7 \mathrm{~b}, 8 \mathrm{~b}$, $9 b, 10,11,12)$. In a dry round bottom flask, 1 eq carboxylic acid, 1.05 eq $\mathrm{O}$-(7-azabenzo-triazole-1-yl)-N,N,N',N'-tetramethyluronium hexafluorophosphate (HATU) and 1.1 eq 1-hydroxy-7-azabenzotriazole (HOAt) were dissolved in $3 \mathrm{~mL}$ dry DMF. The solution was cooled to $0^{\circ} \mathrm{C}$ and 1.3 eq diisopropylethylamine (DIPEA) were added. The resulting yellow solution was stirred for 3 minutes, then 1 eq amine was added and the reaction was stirred overnight at room temperature. After completion, the reaction was quenched with ice and the solvent was evaporated in vacuo. The residue was purified by preparative HPLC $(10 \%-80 \%$ methanol in water).

3 HRMS-ESI (m/z): [M + Na] $]^{+}$calcd for $\mathrm{C}_{23} \mathrm{H}_{27} \mathrm{NO}_{7} \mathrm{Na:}$ : 452.1680, found: 452.1680 .

4 HRMS-ESI (m/z): $\left[\mathrm{M}+\mathrm{Na}^{+}\right.$calcd for $\mathrm{C}_{27} \mathrm{H}_{35} \mathrm{NO}_{7} \mathrm{Na}: 508.2311$, found: 508.2497

7b HRMS-ESI (m/z): $[\mathrm{M}+\mathrm{Na}]^{+}$calcd for $\mathrm{C}_{30} \mathrm{H}_{39} \mathrm{NO}_{7} \mathrm{Na}: 548.2619$, found: 548.2602

8b HRMS-ESI (m/z): [M + Na] $]^{+}$calcd for $\mathrm{C}_{34} \mathrm{H}_{46} \mathrm{~N}_{2} \mathrm{O}_{6} \mathrm{Na:} 633.3146$, found: 633.3171

9b HRMS-ESI (m/z): $[\mathrm{M}+\mathrm{Na}]^{+}$calcd for $\mathrm{C}_{38} \mathrm{H}_{54} \mathrm{~N}_{2} \mathrm{O}_{8} \mathrm{Na}: 689.3772$, found: 689.3775

10 HRMS-ESI (m/z): $[\mathrm{M}+\mathrm{Na}]^{+}$calcd for $\mathrm{C}_{32} \mathrm{H}_{35} \mathrm{NO}_{7} \mathrm{Na}: 568.2306$, found: 568.2285

11 HRMS-ESI (m/z): $[\mathrm{M}+\mathrm{Na}]^{+}$calcd for $\mathrm{C}_{36} \mathrm{H}_{42} \mathrm{~N}_{2} \mathrm{O}_{8} \mathrm{Na}: 653.2833$, found 653.2863.

12 HRMS-ESI (m/z): [M + Na] ${ }^{+}$calcd for $\mathrm{C}_{40} \mathrm{H}_{50} \mathrm{~N}_{2} \mathrm{O}_{8} \mathrm{Na}: 709.3459$, found: 709.3457

Synthesis of the hCE1-sensitive motif tosylate salt of cyclopentyl Lleucinate (5). Cyclopentanol $(28.00 \mathrm{~mL}, 305 \mathrm{mmol})$ and p-toluene sulfonic acid $(6.43 \mathrm{~g}, 33.3 \mathrm{mmol})$ were added to a suspension of $\mathrm{L}$ leucine $(4.062 \mathrm{~g}, 30.5 \mathrm{mmol})$ in cyclohexane $(150 \mathrm{~mL})$. The vessel was fitted with a Dean-Stark receiver and slowly heated to $120^{\circ} \mathrm{C}$ for complete dissolution of the reactants. Temperature was maintained at $120^{\circ} \mathrm{C}$ for a period of 12 hours. The reaction was then cooled to room temperature, which lead to precipitation of a white solid. The solid was filtered and washed with EtOAc before drying in vacuo using a desiccator. Yield $9.630 \mathrm{~g}(85 \%) ;{ }^{1} \mathrm{H}$ NMR (300 MHz, DMSO-d6, $\left.\delta, \mathrm{ppm}, \mathrm{J} / \mathrm{Hz}\right): 7.63$ - 7.77 (m, $2 \mathrm{H}$, tosyl protons), 7.23 (dd, $J=8.7,0.7,2 \mathrm{H}$, tosyl protons), 5.26 $5.32(\mathrm{~m}, 1 \mathrm{H}), 3.95$ (t, J=6.9, $1 \mathrm{H}), 2.37(\mathrm{~s}, 3 \mathrm{H}), 1.85-2.00(\mathrm{~m}, 2 \mathrm{H}), 1.60$ - $1.83(\mathrm{~m}, 8 \mathrm{H}$, cyclopentyl protons), 0.99 (dd, $J=5.8,6 \mathrm{H}$, leucine); HRMS-ESI $(\mathrm{m} / \mathrm{z}):\left[\mathrm{M}+\mathrm{H}^{+}\right.$calcd for $\mathrm{C}_{11} \mathrm{H}_{21} \mathrm{NO}_{2}: 200.1645$, found: 200.1700 .

Synthesis of the hCE1-sensitive motif chloride salt of cyclopentyl Lphenylglycinate (6). To a slurry of L-phenylglycine $(3.054 \mathrm{~g}, 20 \mathrm{mmol})$ in cyclopentanol $(20 \mathrm{~mL})$ in an ice bath, thionyl chloride $(5.19 \mathrm{~mL}, 70 \mathrm{mmol})$ was added dropwise over the period of $5 \mathrm{~min}$ from an automatic pipette with a polyethylene tip. The resulting mixture was kept at $0^{\circ} \mathrm{C}$ for approximately 15 min before it was gently heated to $120^{\circ} \mathrm{C}$ (using an oil 
bath) for $12 \mathrm{~h}$. Then it was left over night at RT for crystallization. The solid was filtered and washed with EtOAc before drying in vacuo in a desiccator. Yield $1.910 \mathrm{~g}(37 \%)$; ${ }^{1} \mathrm{H}$ NMR (300 MHz, DMSO-d6, $\delta, \mathrm{ppm}$, $\mathrm{J} / \mathrm{Hz}$ ): 8.99 (br. s., $3 \mathrm{H},-\mathrm{NH} 3+$ ), 7.37 - 7.53 (m, $5 \mathrm{H}$, phenyl), 5.13 - 5.20 $(\mathrm{m}, 2 \mathrm{H}), 1.31$ - 1.94 (m, $8 \mathrm{H}$, cyclopentyl protons); HRMS-ESI (m/z): [M + $\mathrm{H}]^{+}$calcd for $\mathrm{C}_{13} \mathrm{H}_{18} \mathrm{NO}_{2}: 220.1332$, found: 220.1378 .

General procedure for synthesis of metabolites $(7 a, 8 a, 9 a)$. In a round bottom flask, 1 eq free carboxylic acid, 1.05 eq O-(7-azabenzotriazole-1-yl)-N,N,N',N'-tetramethyluronium hexafluoro-phosphate (HATU) and 1.1 eq 1-hydroxy-7-azabenzotriazole (HOAt) were dissolved in $3 \mathrm{~mL}$ dry DMF. The solution was cooled to $0^{\circ} \mathrm{C}$ and $2.3 \mathrm{eq}$ diisopropylethylamine (DIPEA) were added. The resulting yellow solution was stirred for 3 minutes, then 1 eq L-leucine tert-butyl ester hydrochloride was added and the reaction was stirred overnight at room temperature. After completion, the reaction was quenched with ice. The resulting precipitate was filtered and dissolved in a 1:1 mixture of DCM and TFA. This solution was stirred for 15 minutes at room temperature, and then the solvents were removed in vacuo. The residue was purified by preparative HPLC (10\%-80\% methanol in water)

7a HRMS-ESI (m/z): $[\mathrm{M}+\mathrm{Na}]^{+}$calcd for $\mathrm{C}_{25} \mathrm{H}_{31} \mathrm{NO}_{7} \mathrm{Na}: 480.1993$, found: 480.1989 .

8a HRMS-ESI (m/z): [M - H] calcd for $\mathrm{C}_{29} \mathrm{H}_{37} \mathrm{~N}_{2} \mathrm{O}_{8}: 541.2555$, found: 541.2557.

9a HRMS-ESI (m/z): [M - H] calcd for $\mathrm{C}_{33} \mathrm{H}_{45} \mathrm{~N}_{2} \mathrm{O}_{8}$ : 597.3170, found: 597.3173.

Synthesis of 10-demethoxy-10-aminocolchicine (13). $0.399 \mathrm{~g}$ (1 mmol) of colchicine were mixed with $2 \mathrm{~mL}$ of $\mathrm{NH}_{4} \mathrm{OH} 25 \%$ and $0.5 \mathrm{~mL}$ of $96 \%$ ethanol. The mixture was placed in a $10 \mathrm{~mL}$ microwave reaction tube and placed for $15 \mathrm{~min}$, at $110^{\circ} \mathrm{C}$ and $1200 \mathrm{rpm}$ in a MW reactor. After that it was checked by TLC, diluted with water and extracted with EtOAc. The extract was dried over $\mathrm{MgSO}_{4}$, filtered and resulting solution checked by TLC again. Afterwards, the compound was purified by flash column chromatography with evaporation of the solvent at rotary evaporator and finally dried in vacuo, using a vacuum desiccator for approximately $24 \mathrm{~h}$. Yield $0.289 \mathrm{~g}(75 \%)$. ${ }^{1} \mathrm{H}$ NMR $\left(300 \mathrm{MHz}, \mathrm{CD}_{3} \mathrm{OD}, \delta\right.$, ppm, J/Hz): $7.12(1 \mathrm{H}, \mathrm{s}) 6.74(1 \mathrm{H}, \mathrm{s}) 3.91(3 \mathrm{H}, \mathrm{s}) 3.89(3 \mathrm{H}, \mathrm{s}) 3.57(3$ $\mathrm{H}, \mathrm{s}) 2.02(3 \mathrm{H}, \mathrm{s})$. HRMS-ESI (m/z): $[\mathrm{M}+\mathrm{Na}]^{+}$calcd for $\mathrm{C}_{21} \mathrm{H}_{24} \mathrm{~N}_{2} \mathrm{O}_{5} \mathrm{Na}$ : 407.1577, found: 407.1837 .

General procedure for the synthesis of colchicine-amino acid derivatives (14a-d). To a solution of colchicine $(80 / 160 \mathrm{mg})$ in $0.5 \mathrm{~mL}$ of $96 \% \mathrm{EtOH}$, the 10 -fold molar equivalent of the appropriate amino acid $\gamma$ aminobutyric acid (for 15b, 16), (S)-(-)-4-amino-2-hydroxybutyric acid (for 17b, 18), $\varepsilon$-aminocaproic acid (for 19b), 8-aminooctanoic acid (for 20b) and $0.6 \mathrm{~mL} 1 \mathrm{M} \mathrm{NaOH}$ in $1.55 \mathrm{~mL}$ distilled water were added. The resulting mixture was then stirred for $24 \mathrm{~h}$ at $1000 \mathrm{rpm}$. The end of the occurring reaction was confirmed by TLC. As a next step, the mixture was acidulated with $1 \mathrm{M} \mathrm{HCl}$ until it reached a $\mathrm{pH}$-value of 5-6 depending on the acid used. Then the organic solvent was carefully removed in vacuo in a rotary evaporator and the water layer extracted with $3 \times 15 \mathrm{~mL}$ EtOAc. The obtained extract was then dried over $\mathrm{MgSO}_{4}$, filtered and resulting solution checked by TLC again. In the following, the compound was purified by flash column chromatography with evaporation of the solvent at rotary evaporator and finally dried in vacuo, using a vacuum desiccator for approximately $24 \mathrm{~h}$.

14a Yield $0.140 \mathrm{~g}(74 \%) .{ }^{1} \mathrm{H}$ NMR $\left(300 \mathrm{MHz}, \mathrm{CD}_{3} \mathrm{OD} \delta, \mathrm{ppm}, \mathrm{J} / \mathrm{Hz}\right): 7.40$ (d, J=11.4 Hz, $1 \mathrm{H}), 7.25(\mathrm{~s}, 1 \mathrm{H}), 6.82(\mathrm{~d}, J=11.4 \mathrm{~Hz}, 1 \mathrm{H}), 6.67(\mathrm{~s}, 1 \mathrm{H})$, 4.47 (dd, J=12.0, $6.2 \mathrm{~Hz}, 1 \mathrm{H}), 3.85\left(\mathrm{~s}, 3 \mathrm{H},-\mathrm{OCH}_{3}\right), 3.84(\mathrm{~s}, 3 \mathrm{H}$, $\left.\mathrm{OCH}_{3}\right), 3.52\left(\mathrm{~s}, 3 \mathrm{H},-\mathrm{OCH}_{3}\right), 3.42(\mathrm{t}, J=7.0 \mathrm{~Hz}, 2 \mathrm{H}), 2.35$ (t, $J=7.0 \mathrm{~Hz}, 2$ H), 2.07 - 2.30 (m, $2 \mathrm{H}), 1.99 \mathrm{ppm}(\mathrm{s}, 3 \mathrm{H},-\mathrm{NAc})$. HRMS-ESI (m/z): [M + $\mathrm{H}]^{+}$calcd for $\mathrm{C}_{25} \mathrm{H}_{30} \mathrm{~N}_{2} \mathrm{O}_{7}$ : 471.2126 , found: 471.2442 ; $[\mathrm{M}+\mathrm{Na}]^{+}$calcd for $\mathrm{C}_{25} \mathrm{H}_{30} \mathrm{~N}_{2} \mathrm{O}_{7} \mathrm{Na}: 493.1945$, found: 493.2273 . 14b Yield $0.149 \mathrm{~g}(77 \%)$. ${ }^{1} \mathrm{H}$ NMR (300 MHz, $\mathrm{CD}_{3} \mathrm{OD} \delta$, ppm, J/Hz): 7.38 (d, $J=11.4 \mathrm{~Hz}, 1 \mathrm{H}), 7.27(\mathrm{~s}, 1 \mathrm{H}), 6.82(\mathrm{~d}, J=11.6 \mathrm{~Hz}, 1 \mathrm{H}), 6.68(\mathrm{~s}, 1 \mathrm{H})$, 4.49 (dd, J=11.9, $6.1 \mathrm{~Hz}, 1 \mathrm{H}), 3.87\left(\mathrm{~s}, 3 \mathrm{H},-\mathrm{OCH}_{3}\right), 3.86\left(\mathrm{~s}, 3 \mathrm{H},-\mathrm{OCH}_{3}\right)$, $3.53\left(\mathrm{~s}, 3 \mathrm{H},-\mathrm{OCH}_{3}\right), 2.48-2.58(\mathrm{~m}, 1 \mathrm{H}), 2.11-2.32(\mathrm{~m}, 3 \mathrm{H}), 1.99 \mathrm{ppm}$ (s, $3 \mathrm{H}$, -NAc). HRMS-ESI (m/z): $[\mathrm{M}+\mathrm{Na}]+$ calcd for $\mathrm{C}_{25} \mathrm{H}_{30} \mathrm{~N}_{2} \mathrm{O}_{8} \mathrm{Na}$ : 509.1894, found: 509.1898 .

14c Yield $0.032 \mathrm{~g} \mathrm{(52 \% ).}{ }^{1} \mathrm{H}$ NMR $\left(300 \mathrm{MHz}, \mathrm{CDCl}_{3} \delta, \mathrm{ppm}, \mathrm{J} / \mathrm{Hz}\right): \delta=$ $7.51(\mathrm{~s}, 1 \mathrm{H}), 7.44(\mathrm{~d}, J=11.3 \mathrm{~Hz}, 1 \mathrm{H}), 6.63(\mathrm{~d}, J=11.4 \mathrm{~Hz}, 1 \mathrm{H}), 6.52$ (s, $1 \mathrm{H}), 4.67$ (dd, J=11.8, $5.9 \mathrm{~Hz}, 1 \mathrm{H}), 3.91(\mathrm{~s}, 3 \mathrm{H}), 3.87(\mathrm{~s}, 3 \mathrm{H}), 3.58(\mathrm{~s}, 3$ $\mathrm{H}), 2.40-2.51(\mathrm{~m}, 1 \mathrm{H}), 2.15-2.38(\mathrm{~m}, 4 \mathrm{H}), 1.97(\mathrm{~s}, 3 \mathrm{H}), 1.62-1.83$ $(\mathrm{m}, 5 \mathrm{H}), 1.43-1.55 \mathrm{ppm}(\mathrm{m}, 2 \mathrm{H})$. HRMS-ESI $(\mathrm{m} / \mathrm{z}):[\mathrm{M}+\mathrm{Na}]^{+}$calcd for $\mathrm{C}_{27} \mathrm{H}_{33} \mathrm{~N}_{2} \mathrm{O} 7 \mathrm{Na}: 521.2264$, found: 521.2232 .

14d Yield $0.151 \mathrm{~g}(96 \%) .{ }^{1} \mathrm{H}$ NMR (300 MHz, $\mathrm{CD}_{3} \mathrm{OD} \delta$, ppm, J/Hz): 7.43 (d, $J=11.4 \mathrm{~Hz}, 1 \mathrm{H}), 7.26(\mathrm{~s}, 1 \mathrm{H}), 6.82(\mathrm{~d}, J=11.4 \mathrm{~Hz}, 1 \mathrm{H}), 6.70(\mathrm{~s}, 1 \mathrm{H})$, 4.49 (dd, $J=12.1,6.2 \mathrm{~Hz}, 1 \mathrm{H}), 3.88\left(\mathrm{~s}, 3 \mathrm{H},-\mathrm{OCH}_{3}\right), 3.87\left(\mathrm{~s}, 3 \mathrm{H},-\mathrm{OCH}_{3}\right)$, $3.54\left(\mathrm{~s}, 3 \mathrm{H},-\mathrm{OCH}_{3}\right), 1.99$ (s, $\left.3 \mathrm{H},-\mathrm{NAc}\right), 1.74$ (quin, J=7.1 Hz, $2 \mathrm{H}$ ), 1.61 (quin, J=7.2 Hz, $2 \mathrm{H}), 1.31-1.50 \mathrm{ppm}(\mathrm{m}, 8 \mathrm{H})$. HRMS-ESI (m/z): [M + $\mathrm{Na}]^{+}$calcd for $\mathrm{C}_{29} \mathrm{H}_{38} \mathrm{~N}_{2} \mathrm{O}_{7} \mathrm{Na}: 549.2571$, found: 549.2639

General procedure for the synthesis of compounds $15 \mathrm{~b}, 16,17 \mathrm{~b}, 18$, 19b, 20b by coupling hCE1-sensitive motifs with a C-10demethoxyolchicine amino acid derivative. The carboxylic acid (14ad) was dissolved in $3 \mathrm{~mL}$ of dry DMF by stirring at RT. A double, respectively threefold molar equivalent of diisopropylethylamine (DIPEA) was added by syringe and stirred 10 minutes. Then a double molar equivalent of $\mathrm{O}$-(7-azabenzo-triazole-1-yl)-N,N,N',N'-tetramethyluronium hexafluoro-phosphate (HATU) was added as a solid and the resulting clear solution was stirred for $10 \mathrm{~min}$ at RT. The appropriate hCE1sensitive motif $(1,2)$ was added in a surplus (up to fivefold molar equivalent) and the resulting solution was stirred $24 \mathrm{~h}$. Completion of the reaction was monitored by TLC. Then the solution was diluted with water and extracted with $3 \times 15 \mathrm{~mL}$ EtOAc. The received extract was then dried over $\mathrm{MgSO}_{4}$, filtered and the resulting solution was checked by TLC again In the following, the compound was purified by flash column chromatography and finally dried in vacuo, using a vacuum desiccator for approximately $24 \mathrm{~h}$.

15b Yield $0.015 \mathrm{~g}$ (38\%). ${ }^{1} \mathrm{H}$ NMR $\left(300 \mathrm{MHz}, \mathrm{CD}_{3} \mathrm{OD} \delta, \mathrm{ppm}, \mathrm{J} / \mathrm{Hz}\right): 7.97$ $(\mathrm{s}, 1 \mathrm{H}), 7.44(\mathrm{~d}, J=11.3 \mathrm{~Hz}, 1 \mathrm{H}), 7.26(\mathrm{~s}, 1 \mathrm{H}), 6.87(\mathrm{~d}, J=11.4 \mathrm{~Hz}, 1 \mathrm{H})$ $6.71(\mathrm{~s}, 1 \mathrm{H}), 4.50$ (dd, J=12.2, $6.2 \mathrm{~Hz}, 1 \mathrm{H}), 4.32-4.39(\mathrm{~m}, 1 \mathrm{H}), 3.88$ (s, $\left.3 \mathrm{H},-\mathrm{OCH}_{3}\right), 3.86\left(\mathrm{~s}, 3 \mathrm{H},-\mathrm{OCH}_{3}\right), 3.54\left(\mathrm{~s}, 3 \mathrm{H},-\mathrm{OCH}_{3}\right), 2.01-2.49(\mathrm{~m}, 6$ $\mathrm{H}), 1.99$ (s, $3 \mathrm{H},-\mathrm{NAc}), 1.52-1.97$ (m, $8 \mathrm{H}$, cyclopentyl protons), 0.90 ppm (dd, $J=11.2,6.4 \mathrm{~Hz}, 6 \mathrm{H}, 2 \mathrm{CH}_{3}$ leucine protons). HRMS-ESI (m/z): $[\mathrm{M}+\mathrm{H}]^{+}$calcd for $\mathrm{C}_{36} \mathrm{H}_{49} \mathrm{~N}_{3} \mathrm{O}_{8}: 652.3592$, found: 652.3696; $[\mathrm{M}+\mathrm{Na}]^{+}$ calcd for $\mathrm{C}_{36} \mathrm{H}_{49} \mathrm{~N}_{3} \mathrm{O}_{8} \mathrm{Na}$ : 674.3412 , found: 674.3520 .

16 Yield $0.015 \mathrm{~g}$ (37\%). ${ }^{1} \mathrm{H}$ NMR (300 MHz, CD ${ }_{3} \mathrm{OD} \delta, \mathrm{ppm}, \mathrm{J} / \mathrm{Hz}$ ): 7.97 (s, $1 \mathrm{H}), 7.46-7.30(\mathrm{~m}, 5 \mathrm{H}$, phenylglycine aromatic protons), 6.85 (dd, $J=11.4,2.3 \mathrm{~Hz}, 1 \mathrm{H}), 6.71(\mathrm{~s}, 1 \mathrm{H}), 5.39(\mathrm{~s}, 1 \mathrm{H}), 3.88\left(\mathrm{~s}, 3 \mathrm{H},-\mathrm{OCH}_{3}\right)$, $3.86\left(\mathrm{~s}, 3 \mathrm{H},-\mathrm{OCH}_{3}\right), 3.53\left(\mathrm{~s}, 3 \mathrm{H},-\mathrm{OCH}_{3}\right), 2.02-2.47(\mathrm{~m}, 6 \mathrm{H}), 1.98(\mathrm{~s}, 3$ $\mathrm{H}$, -NAc), $1.43-1.78 \mathrm{ppm}(\mathrm{m}, 8 \mathrm{H}$, cyclopentyl protons). HRMS-ESI $(\mathrm{m} / \mathrm{z}):[\mathrm{M}+\mathrm{H}]^{+}$calcd for $\mathrm{C}_{38} \mathrm{H}_{45} \mathrm{~N}_{3} \mathrm{O}_{8}: 672.3279$, found: 672.3339 ; $[\mathrm{M}+$ $\mathrm{Na}]^{+}$calcd for $\mathrm{C}_{38} \mathrm{H}_{45} \mathrm{~N}_{3} \mathrm{O}_{8} \mathrm{Na:} 694.3099$, found: 694.3167 .

17b Yield $0.013 \mathrm{~g}(28 \%) .{ }^{1} \mathrm{H}$ NMR $\left(300 \mathrm{MHz}, \mathrm{CD}_{3} \mathrm{OD} \delta, \mathrm{ppm}, \mathrm{J} / \mathrm{Hz}\right): 7.48$ (d, J=11.3 Hz, $1 \mathrm{H}), 7.29$ (s, $1 \mathrm{H}), 6.87(\mathrm{~d}, J=11.3 \mathrm{~Hz}, 1 \mathrm{H}), 6.74(\mathrm{~s}, 1 \mathrm{H})$, $3.92\left(\mathrm{~s}, 3 \mathrm{H},-\mathrm{OCH}_{3}\right), 3.90\left(\mathrm{~s}, 3 \mathrm{H},-\mathrm{OCH}_{3}\right), 3.57$ (s, $\left.3 \mathrm{H},-\mathrm{OCH}_{3}\right), 3.02(\mathrm{~d}$ $J=0.3 \mathrm{~Hz}, 1 \mathrm{H}$ ), $2.88(\mathrm{~d}, \mathrm{~J}=0.7 \mathrm{~Hz}, 1 \mathrm{H}), 2.55-2.65$ (m, $1 \mathrm{H}), 2.21$ (br. s. $4 \mathrm{H}$ ), 2.02 (s, $3 \mathrm{H},-\mathrm{NAc}), 1.48$ - 1.92 (m, $8 \mathrm{H}$ ), 0.88 ppm (dd, J=11.2, 6.3 $\mathrm{Hz}, 6 \mathrm{H}, 2 \mathrm{CH}_{3}$ leucine protons). HRMS-ESI $(\mathrm{m} / \mathrm{z}):[\mathrm{M}+\mathrm{H}]^{+}$calcd for $\mathrm{C}_{36} \mathrm{H}_{49} \mathrm{~N}_{3} \mathrm{O}_{9}$ : 668.3542, found: 668.3609; $\left[\mathrm{M}+\mathrm{Na}^{+}\right.$calcd for $\mathrm{C}_{36} \mathrm{H}_{49} \mathrm{~N}_{3} \mathrm{O}_{9} \mathrm{Na}: 690.3361$, found: 690.3427

18 Yield $0.012 \mathrm{~g}(25 \%) .{ }^{1} \mathrm{H}$ NMR $\left(300 \mathrm{MHz}, \mathrm{CD}_{3} \mathrm{OD} \delta, \mathrm{ppm}, \mathrm{J} / \mathrm{Hz}\right): 7.28$ $7.41(\mathrm{~m}, 5 \mathrm{H}$, phenylglycine aromatic protons), $6.89(\mathrm{~d}, \mathrm{~J}=11.4 \mathrm{~Hz}, 1 \mathrm{H})$, $6.74(\mathrm{~s}, 1 \mathrm{H}), 3.92\left(\mathrm{~s}, 3 \mathrm{H},-\mathrm{OCH}_{3}\right), 3.90\left(\mathrm{~s}, 3 \mathrm{H},-\mathrm{OCH}_{3}\right), 3.57(\mathrm{~s}, 3 \mathrm{H}$, 
$\mathrm{OCH}_{3}$ ), 3.02 (d, J=0.3 Hz, $1 \mathrm{H}$ ), 2.05 (s, $3 \mathrm{H},-\mathrm{NAc}$ ), 2.02 (s, $3 \mathrm{H}$ ), 1.42 1.95 ppm (m, $8 \mathrm{H}$, cyclopentyl protons). HRMS-ESI $(\mathrm{m} / \mathrm{z}):[\mathrm{M}+\mathrm{H}]^{+}$calcd for $\mathrm{C}_{38} \mathrm{H}_{45} \mathrm{~N}_{3} \mathrm{O}_{9}: 688.3229$, found: 688.3282; $[\mathrm{M}+\mathrm{Na}]^{+}$calcd for $\mathrm{C}_{38} \mathrm{H}_{45} \mathrm{~N}_{3} \mathrm{O}_{9} \mathrm{Na}: 710.3048$, found: 710.3125 .

19b Yield $0.066 \mathrm{~g}(91 \%) .{ }^{1} \mathrm{H}$ NMR $\left(300 \mathrm{MHz}, \mathrm{CDCl}_{3} \delta, \mathrm{ppm}, \mathrm{J} / \mathrm{Hz}\right): \delta=$ $6.60(\mathrm{~d}, J=11.4 \mathrm{~Hz}, 1 \mathrm{H}), 6.54(\mathrm{~s}, 1 \mathrm{H}), 6.10$ (d, J=8.1 Hz, $1 \mathrm{H}), 3.94$ (s, 3 $\left.\mathrm{H},-\mathrm{OCH}_{3}\right), 3.90\left(\mathrm{~s}, 3 \mathrm{H},-\mathrm{OCH}_{3}\right), 3.62\left(\mathrm{~s}, 3 \mathrm{H},-\mathrm{OCH}_{3}\right), 2.00(\mathrm{~s}, 3 \mathrm{H},-$ $\mathrm{NAc}), 1.44-1.96(\mathrm{~m}, 18 \mathrm{H}$, cyclopentyl and caproic acid protons), 0.94 ppm ( $J=11.1,6.4 \mathrm{~Hz}, 6 \mathrm{H}, \mathrm{CH}_{3}$ leucine protons). HRMS-ESI $(\mathrm{m} / \mathrm{z}):[\mathrm{M}+$ $\mathrm{Na}]^{+}$calcd for $\mathrm{C}_{38} \mathrm{H}_{53} \mathrm{~N}_{3} \mathrm{O}_{8} \mathrm{Na}: 702.3730$, found: 702.3807 .

20b Yield $0.040 \mathrm{~g}(94 \%) .{ }^{1} \mathrm{H}$ NMR $\left(300 \mathrm{MHz}, \mathrm{CD}_{3} \mathrm{OD} \delta, \mathrm{ppm}, \mathrm{J} / \mathrm{Hz}\right): 7.47$ (d, J=11.3 Hz, 2 H), 7.28 (s, $1 \mathrm{H}), 6.85$ (d, J=11.4 Hz, 2 H), 6.73 (s, $2 \mathrm{H})$, $3.91\left(\mathrm{~s}, 3 \mathrm{H},-\mathrm{OCH}_{3}\right), 3.90\left(\mathrm{~s}, 3 \mathrm{H},-\mathrm{OCH}_{3}\right), 3.57$ (s, $\left.3 \mathrm{H},-\mathrm{OCH}_{3}\right), 2.01$ (s, $3 \mathrm{H}$, -NAc), $1.54-1.92$ (m, $8 \mathrm{H}$, cyclopentyl protons), $1.33-1.53(\mathrm{~m}, 8 \mathrm{H}$, octanoic acid protons), $0.92 \mathrm{ppm}\left(\mathrm{J}=11.1,6.4 \mathrm{~Hz}, 6 \mathrm{H}, 2 \mathrm{CH}_{3}\right.$ leucine protons). HRMS-ESI (m/z): $[\mathrm{M}+\mathrm{Na}]^{+}$calcd for $\mathrm{C}_{40} \mathrm{H}_{57} \mathrm{~N}_{3} \mathrm{O}_{8} \mathrm{Na}: 730.4038$, found: 730.4071 .

Synthesis of 21b: First, to a solution of 4-carboxybenzylaldehyde (348 mg, $2.25 \mathrm{mmol})$ in THF $(25 \mathrm{~mL})$ was added tosylate salt of cyclopentyl L-leucinate (5) $(890 \mathrm{mg}, 2.25 \mathrm{mmol})$ or chloride of cyclopentyl L-phenylgycinate (6) $(0.581 \mathrm{mg}, 2.25 \mathrm{mmol})$, stirred for $60 \mathrm{~min}$, and then portion-wise sodium triacetoxyborohydride (1192 $\mathrm{mg}, 4.5 \mathrm{mmol})$. The mixture was stirred for $18 \mathrm{~h}$ at RT. Then it was diluted with EtOAc and dried over $\mathrm{MgSO}_{4}$, filtered and the resulting solution was checked by TLC again. In the following, the compound was purified by flash column chromatography and finally dried in vacuo, using a vacuum desiccator for approximately $24 \mathrm{~h} .99 \mathrm{mg}(0.3 \mathrm{mmol})$ of the obtained cyclopentyl $\mathrm{N}-(4-$ carboxybenzyl)-L-leucinate or $105 \mathrm{mg}$ of cyclopentyl $\mathrm{N}$-(4carboxybenzyl)-L-phenylglycinate dissolved in $2 \mathrm{~mL}$ DCM and added several drops DMF. Then $22 \mu \mathrm{L} \mathrm{SOCl}_{2}$ were added and the mixture was refluxed for $1 \mathrm{~h}$. After this, the solution of $0.058 \mathrm{~g} 13$ in $1 \mathrm{~mL}$ of pyridine was added and the mixture was stirred at RT for $2 \mathrm{~h}$ more. The organic solvent was washed with water and evaporated under reduced pressure and the water phase extracted three times with $5 \mathrm{~mL}$ EtOAc. The extract was dried over $\mathrm{MgSO}_{4}$, filtered and the resulting solution checked by TLC again. In the following, the compound was purified by flash column chromatography and finally dried in vacuo, using a vacuum desiccator for approximately $24 \mathrm{~h}$.

21b Yield $0.050 \mathrm{~g}(48 \%) .{ }^{1} \mathrm{H} \mathrm{NMR}\left(300 \mathrm{MHz}, \mathrm{CDCl}_{3} \delta, \mathrm{ppm}, \mathrm{J} / \mathrm{Hz}\right): 7.87$ $8.15(\mathrm{~m}, 4 \mathrm{H}), 7.62-7.69(\mathrm{~m}, 2 \mathrm{H}$, aromatic protons $), 7.46-7.59(\mathrm{~m}, 2 \mathrm{H}$, aromatic protons), $6.53-6.56(\mathrm{~m}, 1 \mathrm{H}), 3.97\left(\mathrm{~s}, 3 \mathrm{H},-\mathrm{OCH}_{3}\right), 3.94(\mathrm{~s}, 3$ $\mathrm{H}), 3.66\left(\mathrm{~s}, 3 \mathrm{H},-\mathrm{OCH}_{3}\right), 2.09(\mathrm{~s}, 3 \mathrm{H},-\mathrm{NAc}), 1.56-1.94(\mathrm{~m}, 13 \mathrm{H}), 0.91$ ppm (dd, J=17.1, $6.5 \mathrm{~Hz}, 6 \mathrm{H}, 2 \mathrm{CH}_{3}$ leucine protons). HRMS-ESI (m/z): $[\mathrm{M}+\mathrm{H}]^{+}$calcd for $\mathrm{C}_{40} \mathrm{H}_{49} \mathrm{~N}_{3} \mathrm{O}_{8}$ : 700.3592 , found: 700.3835 ; $[\mathrm{M}+\mathrm{Na}]^{+}$ calcd for $\mathrm{C}_{40} \mathrm{H}_{49} \mathrm{~N}_{3} \mathrm{O}_{8} \mathrm{Na}$ : 722.3412 found: 722.3659 .

General procedure for the synthesis of metabolites (15a, 17a, 19a, 20a, 21a) The metabolites of the studied compounds were synthesized according to the procedures provided above, but replacing the cyclopentyl esters of Leu and Phg with tert-butyl esters of the same amino acids. The obtained tert-butyl derivatives were subjected to hydrolysis with aqueous phosphoric acid as follows: $0.045 \mathrm{mmol}$ of the respective tert-butyl ester were dissolved in $3 \mathrm{~mL} \mathrm{CH}_{2} \mathrm{Cl}_{2}$ and $0.116 \mathrm{~mL}$ of $85 \%$ aqueous phosphoric acid were added dropwise at room temperature. The mixture was vigorously stirred for $3 \mathrm{~h}$ and the reaction checked by HPLC. Then $5 \mathrm{~mL}$ of water was added and the mixture was cooled to $0^{\circ} \mathrm{C}$. A saturated solution of $\mathrm{NaHCO}_{3}$ was added slowly to adjust the $\mathrm{pH}$ to 8 . The mixture was then extracted with EtOAc. The combined organic phase was dried over magnesium sulfate and concentrated in vacuo to obtain the product.

15a HRMS-ESI (m/z): [M - H] calcd for $\mathrm{C}_{31} \mathrm{H}_{41} \mathrm{~N}_{3} \mathrm{O}_{8}$ : 582.2821 , found: 582.2821. 17a ${ }^{1} \mathrm{H}$ NMR $\left(300 \mathrm{MHz}, \mathrm{CD}_{3} \mathrm{OD} \delta, \mathrm{ppm}, \mathrm{J} / \mathrm{Hz}\right): 7.44(\mathrm{~d}, J=11.3 \mathrm{~Hz}, 1 \mathrm{H})$ $7.26(\mathrm{~s}, 1 \mathrm{H}), 6.82(\mathrm{~d}, \mathrm{~J}=11.4 \mathrm{~Hz}, 1 \mathrm{H}), 6.71(\mathrm{~s}, 1 \mathrm{H}), 3.88\left(\mathrm{~s}, 3 \mathrm{H},-\mathrm{OCH}_{3}\right)$, $3.87\left(\mathrm{~s}, 3 \mathrm{H},-\mathrm{OCH}_{3}\right), 3.55$ (s, $\left.3 \mathrm{H},-\mathrm{OCH}_{3}\right), 1.99$ (s, $\left.3 \mathrm{H},-\mathrm{NAc}\right), 1.51$ $1.66(\mathrm{~m}, 3 \mathrm{H}), 0.85 \mathrm{ppm}$ (dd, $J=11.7,6.3 \mathrm{~Hz}, 6 \mathrm{H}, 2 \mathrm{CH}_{3}$ leucine protons). HRMS-ESI (m/z): [M - H]- calcd for $\mathrm{C}_{35} \mathrm{H}_{41} \mathrm{~N}_{3} \mathrm{O}_{8}$ : 630.2821, found: 630.2729 .

19a ${ }^{1} \mathrm{H}$ NMR (300 MHz, CD $\left.{ }_{3} \mathrm{OD} \delta, p p m, J / H z\right): 7.44(\mathrm{~d}, J=11.3 \mathrm{~Hz}, 1 \mathrm{H})$, 7.27 (s, $1 \mathrm{H}), 6.83(\mathrm{~d}, \mathrm{~J}=11.4 \mathrm{~Hz}, 1 \mathrm{H}), 6.70(\mathrm{~s}, 1 \mathrm{H}), 3.88\left(\mathrm{~s}, 3 \mathrm{H},-\mathrm{OCH}_{3}\right)$, 3.87 (s, $\left.3 \mathrm{H},-\mathrm{OCH}_{3}\right), 3.54$ (s, $3 \mathrm{H},-\mathrm{OCH}_{3}$ ), 1.99 (s, $\left.3 \mathrm{H},-\mathrm{NAc}\right), 0.91 \mathrm{ppm}$ (dd, J=6.2, $1.2 \mathrm{~Hz}, 6 \mathrm{H}, 2 \mathrm{CH}_{3}$ leucine protons). HRMS-ESI (m/z): [M - H] calcd for $\mathrm{C}_{33} \mathrm{H}_{45} \mathrm{~N}_{3} \mathrm{O}_{8}: 610.3134$, found: 610.3158 .

20a HRMS-ESI (m/z): [M - H] calcd for $\mathrm{C}_{35} \mathrm{H}_{49} \mathrm{~N}_{3} \mathrm{O}_{8}$ : 638.3447, found: 638.3443.

21a ${ }^{1} \mathrm{H}$ NMR (300 MHz, $\left.\mathrm{CD}_{3} \mathrm{OD} \delta, \mathrm{ppm}, \mathrm{J} / \mathrm{Hz}\right): 7.97-8.04(\mathrm{~m}, \mathrm{~J}=8.4 \mathrm{~Hz}$, $2 \mathrm{H}$, aromatic protons), $7.62-7.69(\mathrm{~m}, \mathrm{~J}=8.4 \mathrm{~Hz}, 2 \mathrm{H}$, aromatic protons), $7.52(\mathrm{~s}, 1 \mathrm{H}), 7.48(\mathrm{~d}, \mathrm{~J}=10.8 \mathrm{~Hz}, 1 \mathrm{H}), 6.75(\mathrm{~s}, 1 \mathrm{H}), 3.90(\mathrm{~s}, 3 \mathrm{H}$, $\left.\mathrm{OCH}_{3}\right), 3.89\left(\mathrm{~s}, 3 \mathrm{H},-\mathrm{OCH}_{3}\right), 3.61\left(\mathrm{~s}, 3 \mathrm{H},-\mathrm{OCH}_{3}\right), 2.00 \mathrm{ppm}(\mathrm{s}, 3 \mathrm{H}$, $\mathrm{NAc}$ ), $0.94 \mathrm{ppm}$ (dd, J=6.2, $1.2 \mathrm{~Hz}, 6 \mathrm{H}, 2 \mathrm{CH}_{3}$ leucine protons). HRMSESI (m/z): [M - H] calcd for $\mathrm{C}_{31} \mathrm{H}_{41} \mathrm{~N}_{3} \mathrm{O}_{9}$ : 598.2770, found: 598.2762.

Expression and Purification of the Human Carboxylesterase 1. Human carboxylesterase was expressed in Sf9 insect cells using the baculovirus expression system. In brief, the coding sequence of hCE1 was amplified from cDNA of HeLa cells and cloned into pFASTBac1 vector by a PCR-based cloning approach using the primer pair RF hCE FW (CACCATCGGGCGCGGATATGTGGCTCCGTGCCT) and RF_hCE_REV (GCTGATTATGATCCTCTAGTACTTCTCGACAAGCTA GTGATGGTGATGGTGATGCAGCTCTATGTGTTCTGTCTGG). E. coli $\mathrm{DH} 10 \mathrm{Bac}$ cells were transformed with the resulting plasmid, pFastBac1hCE1, in order to generate recombinant bacmid. The extracted recombinant bacmid DNA was transfected into Sf9 cells using Cellfectin transfection reagent (Thermo Fisher Scientific) according to the supplier's instruction manual in order to generate recombinant baculoviruses. After $72 \mathrm{~h}$, supernatant was harvested and viral titre was determined by plaque assay. For expression of hCE1, Sf9 cells were infected with recombinant baculovirus with a multiplicity of infection (MOI) of 10 and incubated for $72 \mathrm{~h}$ at $27^{\circ} \mathrm{C}$. After harvesting the cells by centrifugation with $1000 \times \mathrm{g}$ for $15 \mathrm{~min}$, cells were lysed by adding lysis buffer (50 mM HEPES, $\mathrm{pH} 7.5$, $150 \mathrm{mM} \mathrm{NaCl}, 5 \mathrm{mM}$ 2-mercaptoethanol, 0.05\% Triton-X-100) and sonication. Insoluble components were separated by centrifugation at $4^{\circ} \mathrm{C}$ with $45000 \times \mathrm{g}$ for $45 \mathrm{~min}$. The hCE1 protein was subsequently purified by Ni-affinity chromatography and size exclusion chromatography.

Virus Titre Reduction Assay (Plaque Assay). Huh-7 and Vero E6 cells were maintained in Dulbecco's Modified Eagle's Medium (DMEM) supplemented with $10 \%$ fetal bovine serum, 100 units penicillin $\mathrm{G}$ per $\mathrm{mL}$ and $0.1 \mathrm{mg} / \mathrm{mL}$ streptomycin (DMEMcplt) at $37^{\circ} \mathrm{C}, 5 \% \mathrm{CO}_{2}$ and $95 \%$ relative humidity. For assessing cytotoxicity, $10^{4}$ Huh-7 cells per well were seeded into 96-well plates in $50 \mu \mathrm{L}$ DMEMcplt and incubated overnight at $37^{\circ} \mathrm{C}$. On the next day, the cells were infected with wild type DENV serotype 2 with a multiplicity of infection (MOI) of 1 in presence of the respective concentration of the tested compound in triplicates. After incubation for $48 \mathrm{~h}$ at $37^{\circ} \mathrm{C}$ the medium was harvested, the triplicates were pooled and stored at $-80^{\circ} \mathrm{C}$ until further usage. $50 \mu \mathrm{l}$ of fresh DMEMcplt was added to the cells and cell viability was determined using Cell-Titer Glo Luminescent Viability Assay (Promega). For measurement of virus titres by plaque assay, Vero E6 cells were seeded into 24-well plates with a density of $2.5 \times 10^{5}$ cells per well. After overnight incubation at $37^{\circ} \mathrm{C}$, the cells were infected with the harvested virus supernatant. The virus containing medium was diluted with DMEMcplt ranging from $10^{-1}$ to $10^{-6}$ prior to infection. After incubation of the cells with $100 \mu \mathrm{l}$ of the virus dilution at $37^{\circ} \mathrm{C}$ with agitation for $1 \mathrm{~h}$, the medium was removed and $1 \mathrm{~mL}$ of plaque medium was added. After further incubation for 7 days at $37^{\circ} \mathrm{C}$ the cells were fixed with $5 \%(\mathrm{v} / \mathrm{v})$ formaldehyde for $2 \mathrm{~h}$, stained with 
crystal violet and plaques were counted. Titre reduction was calculated compared to a control treated with DMSO alone.

Toxicity Assay. Determination of cell viability was performed using the Cell Titer Blue assay with HeLa or Huh7 cells. All tested compounds were diluted in a dilution series from $50 \mu \mathrm{M}$ down to $3.2 \mathrm{nM}$ in a sterile flat-bottom 96-well plate with a zero compound control. HeLa and Huh7cells are cultivated in Dulbecco's modified Eagle Medium (DMEM). After splitting, the cells were diluted with DMEM and $5000 \mathrm{HeLa}$ cells or 7000 Huh7 cells were put into each well of the initial plate and incubated for 24 and $72 \mathrm{~h}$ at $37^{\circ} \mathrm{C}$. After the incubation, the medium was removed with a vacuum pump and $100 \mu \mathrm{L}$ of a mixture of $20 \%$ Resazurin and $80 \%$ DMEM was aliquoted into the wells. The dye was incubated for $2 \mathrm{~h}$ at $37^{\circ} \mathrm{C}$. Afterwards, the percentage of cell viability was calculated by the difference of absorption at $570 \mathrm{~nm}$ and $600 \mathrm{~nm}$. $\mathrm{CC}_{50}$ values were obtained after plotting cell viability versus the logarithmic concentration and applying a dose-response fit in GraphPad Prism 7.

Hydrolysis of compounds by hCE1. The biochemical assay was performed in a 96-well U-bottom plate. In assay buffer $(20 \mathrm{mM}$ phosphate $\mathrm{pH} 7.4$ with $40 \mathrm{mM} \mathrm{KCl}$ ), a $10 \mathrm{mM}$ compound stock solution in DMSO was diluted to $10 \mu \mathrm{M}$. hCE1 solution was added to a final concentration of $100 \mathrm{nM}$. The plate was incubated at $37^{\circ} \mathrm{C}$ for $2 \mathrm{~h}$. Subsequently, the assay was quenched with the addition of $30 \mu \mathrm{L}$ acetonitrile per well. The relative concentration of the compound was then determined by integration of HPLC signals and compared to a control without enzyme. In cases where no cleavage was observed in $2 \mathrm{~h}$, the compounds were incubated for $24 \mathrm{~h}$ in order to confirm the lack of cleavage.

Tubulin Polymerization Assay. The assay was performed in a 96-well flat-bottom plate using a porcine tubulin polymerization assay kit by tebubio $\mathrm{GmbH}$ (Germany). To prepare the $5 \mathrm{mg} / \mathrm{mL}$ stock solution of tubulin 4 $\mathrm{mg}$ of lyophilized tubulin was dissolved in $800 \mu \mathrm{L}$ of cold "general tubulin buffer" (GTB, $80 \mathrm{mM}$ PIPES, $0.5 \mathrm{mM}$ EGTA, $2 \mathrm{mM} \mathrm{MgCl}$, pH 6.9). $100 \mu \mathrm{M}$ stock solutions of the analysed compounds were prepared by diluting $0.1 \mathrm{~mL}$ of the $10 \mathrm{mM}$ DMSO based solution of the compound in $9.9 \mathrm{~mL}$ GTB. In each analytical well $80 \mu \mathrm{L}$ of tubulin solution in GTB, $10 \mu \mathrm{L} 10 \mathrm{X}$ compound solution in GTB, $10 \mu \mathrm{L}$ GTP solution in GTB were added reaching the respective final concentrations of $4 \mathrm{mg} / \mathrm{mL}$ tubulin, $10 \mu \mathrm{M}$ compound, and $1 \mathrm{mM}$ GTP. In each control well $80 \mu \mathrm{L}$ of tubulin solution in GTB, $10 \mu \mathrm{L}$ of DMSO in GTB $(0.1 \mathrm{~mL}$ in $9.9 \mathrm{~mL})$, and $10 \mu \mathrm{L}$ GTP in GTB were added to yield final concentrations of $4 \mathrm{mg} / \mathrm{mL}$ for tubulin and $1 \mathrm{mM}$ for GTP. Procedure: The plate was incubated at $37^{\circ} \mathrm{C}$ for $30 \mathrm{~min}$ with added solutions of tubulin and the test compound, followed by chilling to $0^{\circ} \mathrm{C}$ to depolymerize formed microtubules. Subsequently, GTP solution was added. Immediately after the addition of GTP, the read-out began. For read-out, the absorption at $340 \mathrm{~nm}$ and $37^{\circ} \mathrm{C}$ was measured by a microtiter plate reader (BMG labtech Omega).

Molecular modelling studies. Docking simulation study was performed using Molecular Operating Environment (MOE) C.C.G.I., (2015), 1010 Sherbooke St. West, Suite \#910, Montreal, QC, Canada, H3A 2R7. The computational software operated under Windows 8 Pro (64 bit) installed on a DELL Precision T7610 (v3) Work Station. The X-ray crystallographic structure of tubulin in a complex with colchicine was obtained from a protein database via the Internet (http://www.RCSB.org/, PDB code 4OB2 $)^{[58]}$. The corresponding structure of combretastatin was also obtained from the PDB bank, code $1 \mathrm{LYJ}{ }^{[25]}$. The energy of all conformers was minimized in an automatic mode until the RMSD gradient of $0.01 \mathrm{kcal} / \mathrm{mol}$ was achieved, and the mean square distance of $0.1 \AA$ was calculated with the force field MMFF94X.

\section{Acknowledgements}

VB is very grateful for a very generous funding under the Georg Forster Research Fellowship received from the Alexander von Humboldt Foundation.

The authors thankfully acknowledge the technical assistance of Stephanie Kallis for the ZIKV antiviral assay, Natascha Stefan for the help in cell culture and Heiko Rudy for the mass spectral data.

MR thanks Torben LangHeinrich for his assistance in the synthesis of compound 9 a.

Keywords: tubulin ligand, dengue, Zika, combretastatin, colchicine, prodrug

\section{References:}

[1] S. Bhatt, P. W. Gething, O. J. Brady, J. P. Messina, A. W. Farlow, C L. Moyes, J. M. Drake, J. S. Brownstein, A. G. Hoen, O. Sankoh, et al., Nature 2013, 496, 504-507.

[2] J. D. Stanaway, D. S. Shepard, E. A. Undurraga, Y. A. Halasa, L. E. Coffeng, O. J. Brady, S. I. Hay, N. Bedi, I. M. Bensenor, C. A. Castañeda-Orjuela, et al., Lancet Infect. Dis. 2016, 16, 712-723.

[3] S. C. Weaver, W. K. Reisen, Antiviral Res. 2010, 85, 328-345.

[4] V. Boldescu, M. A. M. Behnam, N. Vasilakis, C. D. Klein, Nat. Rev. Drug Discov. 2017, 16, 565-586.

[5] S. H. E. Kaufmann, A. Dorhoi, R. S. Hotchkiss, R. Bartenschlager, Nat. Rev. Drug Discov. 2018, 17, 35-56.

[6] W. MacRae, J. Hudson, G. Towers, Planta Med. 1989, 55, 531-535

[7] M. Cortese, S. Goellner, E. G. Acosta, C. J. Neufeldt, O. Oleksiuk, M. Lampe, U. Haselmann, C. Funaya, N. Schieber, P. Ronchi, et al., Cell Rep. 2017, 18, 2113-2123.

[8] M. Satake, R. B. Luftig, J. Gen. Virol. 1982, 58, 339-349.

[9] K. Y. Foo, H. Chee, Biomed Res. Int. 2015, 2015, 1-6.

[10] E. G. Acosta, V. Castilla, E. B. Damonte, J. Gen. Virol. 2008, 89, 474-484.

[11] M. S. Paingankar, M. D. Gokhale, D. N. Deobagkar, Arch. Virol. 2010, 155, 1453-1461.

[12] W. Chen, N. Gao, J. L. Wang, Y. P. Tian, Z. T. Chen, J. An, Arch. Virol. 2008, 153, 1777-1781.

[13] U. F. Greber, Cell. Mol. Life Sci. 2002, 59, 608-626.

[14] R. Thayan, T. L. Huat, L. L. C. See, N. S. Khairullah, R. Yusof, S. Devi, Southeast Asian J. Trop. Med. Public Health 2009, 40, 56-65. [15] E. G. Acosta, V. Castilla, E. B. Damonte, Cell. Microbiol. 2009, 11, 1533-1549.

[16] H. Y. Chee, S. AbuBakar, Biochem. Biophys. Res. Commun. 2004, 320, 11-17.

[17] M. Cortese, S. Goellner, E. G. Acosta, C. J. Neufeldt, O. Oleksiuk, M. Lampe, U. Haselmann, C. Funaya, N. Schieber, P. Ronchi, et al., Cell Rep. 2017, 18, 2113-2123.

[18] B. E. E. Martina, P. Koraka, A. D. M. E. Osterhaus, Clin. Microbiol. Rev. 2009, 22, 564-581.

[19] S. Blackley, Z. Kou, H. Chen, M. Quinn, R. C. Rose, J. J. Schlesinger, M. Coppage, X. Jin, J. Virol. 2007, 81, 13325-13334. V. Boldescu, V. Crudu, N. Sucman, S. Pogrebnoi, M. Zviaghin, E. Stîngaci, V. Pogrebnoi, F. Macaev, Chem. J. Mold. 2013, 8, 21-31. M. Hosokawa, Molecules 2008, 13, 412-31.

[22] L. a Needham, A. H. Davidson, L. J. Bawden, A. Belfield, E. a Bone 
D. H. Brotherton, S. Bryant, M. H. Charlton, V. L. Clark, S. J. Davies, et al., J. Pharmacol. Exp. Ther. 2011, 339, 132-42.

M. H. Charlton, D. F. C. Moffat, S. J. Davies, A. Hastings Drummond, M. Struthers Drummond, Imaging Agents, 2014, US 2014/0010762 A1.

[24] R. B. G. Ravelli, B. Gigant, P. A. Curmi, I. Jourdain, S. Lachkar, A. Sobel, M. Knossow, Nature 2004, 428, 198-202.

[25] R. Gaspari, A. E. Prota, K. Bargsten, A. Cavalli, M. O. Steinmetz, Chem 2017, 2, 102-113.

[26] J. A. Woods, J. A. Hadfield, G. R. Pettit, B. W. Fox, A. T. McGown, Br. J. Cancer 1995, 71, 705-11.

[27] K. Jaroch, M. Karolak, P. Górski, A. Jaroch, A. Krajewski, A. Inicka, A. Sloderbach, T. Stefański, S. Sobiak, Pharmacol. Reports 2016, 68, 1266-1275

[28] M. Medarde, A. B. S. Maya, C. Pérez-Melero, J. Enzyme Inhib. Med. Chem. 2004, 19, 521-40.

[29] R. Mikstacka, T. Stefański, J. Różański, Cell. Mol. Biol. Lett. 2013, 18, 368-97.

[30] G. C. Tron, T. Pirali, G. Sorba, F. Pagliai, S. Busacca, A. A. Genazzani, J. Med. Chem. 2006, 49, 3033-44.

[31] C. Da, S. L. Mooberry, J. T. Gupton, G. E. Kellogg, J. Med. Chem. 2013, 56, 7382-7395.

[32] A. Vandecandelaere, S. R. Martin, P. M. Bayley, M. J. Schilstra, Biochemistry 1994, 33, 2792-2801.

[33] B. Baguley, L. Zhuang, P. Kestell, Oncol. Res. 1997, 9, 55-60.

[34] J. Fournier-Dit-Chabert, V. Vinader, A. R. Santos, M. RedondoHorcajo, A. Dreneau, R. Basak, L. Cosentino, G. Marston, H. AbdelRahman, P. M. Loadman, et al., Bioorganic Med. Chem. Lett. 2012, 22, 7693-7696

[35] M. Roesner, H.-G. Capraro, A. E. Jacobson, L. Atwell, A. Brossi, M. A. lorio, T. H. Williams, R. H. Sik, C. F. Chignell, J. Med. Chem. 1981, 24, 257-261.

[36] A. Huczyński, J. Rutkowski, K. Popiel, E. Maj, J. Wietrzyk, J. Stefańska, U. Majcher, F. Bartl, Eur. J. Med. Chem. 2014, 90, 296301.

[37] Y. B. Malysheva, S. Combes, D. Allegro, V. Peyrot, P. Knochel, A. E. Gavryushin, A. Y. Fedorov, Bioorg. Med. Chem. 2012, 20, 42714278.

[38] N. Yasobu, M. Kitajima, N. Kogure, Y. Shishido, T. Matsuzaki, M. Nagaoka, H. Takayama, ACS Med. Chem. Lett. 2011, 2, 348-352.

[39] E. O. Esbolaev, N. A. Aitkhozhina, L. A. Aleksandrova, Chem. Nat Compd. 1989, 25, 80-83.

[40] Y. L. Garazd, M. M. Garazd, V. G. Kartsev, Chem. Nat. Compd. 2015, 51, 1138-1141.

[41] A. Massarotti, A. Coluccia, R. Silvestri, G. Sorba, A. Brancale, ChemMedChem 2012, 7, 33-42.

[42] A. Farce, C. Loge, S. Gallet, N. Lebegue, P. Carato, P. Chavatte, P. Berthelot, D. Lesieur, J. Enzyme Inhib. Med. Chem. 2004, 19, 541547.

[43] O. M. Aly, E. A. Beshr, R. M. Maklad, M. Mustafa, A. M. GamalEldeen, Arch. Pharm. (Weinheim). 2014, 347, 658-667.

[44] M. Mphahlele, N. Parbhoo, Pharmaceuticals 2018, 11, 59.

[45] M. Zayed, S. Ahmed, S. Inmaid, H. Ahmed, H. Rateb, S. Ibrahim, Int. J. Mol. Sci. 2018, 19, 1731.

[46] S. N. Baytas, N. Inceler, A. Yılmaz, A. Olgac, S. Menevse, E. Banoglu, E. Hamel, R. Bortolozzi, G. Viola, Bioorg. Med. Chem. 2014, 22, 3096-3104.
M.-M. Niu, J. Qin, C. Tian, X. Yan, F.-G. Dong, Z. Cheng, G. Fida, M. Yang, H. Chen, Y. Gu, Acta Pharmacol. Sin. 2014, 35, 967-979.

[48] U. Yadava, V. K. Yadav, R. K. Yadav, RSC Adv. 2017, 7, 1591715925.

[49] Y. Wang, H. Zhang, B. Gigant, Y. Yu, Y. Wu, X. Chen, Q. Lai, Z. Yang, Q. Chen, J. Yang, FEBS J. 2016, 283, 102-111.

[50] B. V. Kumbhar, A. Borogaon, D. Panda, A. Kunwar, PLoS One 2016, 11, e0156048.

[51] R. I. Ahmed, E. E. A. Osman, F. M. Awadallah, S. M. El-Moghazy, J. Enzyme Inhib. Med. Chem. 2017, 32, 176-188.

[52] D. D. Li, Y. J. Qin, X. Zhang, Y. Yin, H. L. Zhu, L. G. Zhao, Chem. Biol. Drug Des. 2015, 86, 731-745.

[53] D. F. Tang-Wai, P. Gros, A. Brossi, L. D. Arnold, Biochemistry 1993, 32, 6470-6476.

[54] S. Bencharit, C. C. Edwards, C. L. Morton, E. L. Howard-Williams, P. Kuhn, P. M. Potter, M. R. Redinbo, J. Mol. Biol. 2006, 363, 201-214.

[55] T. Fukami, M. Kariya, T. Kurokawa, A. lida, M. Nakajima, Eur. J. Pharm. Sci. 2015, 78, 47-53.

[56] S. Casey Laizure, V. Herring, Z. Hu, K. Witbrodt, R. B. Parker, Pharmacother. J. Hum. Pharmacol. Drug Ther. 2013, 33, 210-222.

[57] C. Liang, M. A. M. Behnam, T. R. Sundermann, C. D. Klein, Tetrahedron Lett. 2017, 58, 2325-2329.

[58] A. E. Prota, F. Danel, F. Bachmann, K. Bargsten, R. M. Buey, J. Pohlmann, S. Reinelt, H. Lane, M. O. Steinmetz, J. Mol. Biol. 2014, 426, 1848-60. 


\section{Entry for the Table of Contents}

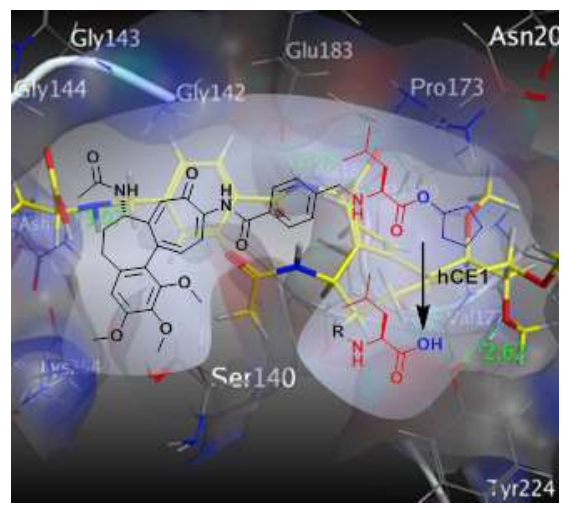

Restraining Dengue and Zika Viruses: Inhibitors of tubulin polymerization can disrupt the reproduction cycle of dengue and Zika viruses, but have limited application due to their high toxicity. We present a series of combretastatin and colchicine prodrugs that are cleaved by hCE1 which is abundant in infected cells. The prodrugs show decreased toxicity and reduce the dengue and Zika virus replication at subcytotoxic concentrations. 